\title{
Geleneksel Konut Dokusunun Korunmasına Yönelik Yaklaşım Önerisi: Geleneksel Tokat Evleri Halit Sokak, Bey Sokak, Beyhamam Sokak
}

\author{
Dilara Gökçen AKÇAY PAÇ ${ }^{1 *}$, Demet ULUSOY BINAN²
}

Öz

Kültürel mirasın somut ve somut olmayan değerlerini kapsayan tarihi kentlerin geçmişten günümüze pek çok döneme tanıklık etmeleri ve bu dönemlere ait izler taşımaları onları önemli kılar. Tokat kenti tarihsel ve kültürel devamlılığı doğrultusunda kendi özgün kimliğini koruyabilmiş kentlerimizdendir. Kentte günümüze ulaşan anıtsal yapılar ve sivil mimarlık örnekleri farklı dönemlerin bütünselliği içinde kentin en temel kültürel çekirdeğini oluşturmaktadır. Geleneksel Tokat evleri için ayrıntılı belgeleme ve çözümleme çalışmalarının değerlendirilmesi ile belirlenen mimari özellikleri, koruma sorunları ve değerleri bağlamında kentin geleneksel konut dokusunun yer aldığı bir sokak üzerinden koruma yaklaşımına yönelik örnekleme yapılmıştır. Tokat kenti için kentsel ölçekte koruma amaçlı değerlendirme, koruma ve yönetim yaklaşımı geliştirilememiş olduğu yalnızca sokak ölçeğinde ön cephelerin onarımlarının yapıldığı bir koruma uygulama yaklaşımının gerçekleştiği tespit edilmiştir. Tokat kenti geleneksel konut dokusunda yer alan; Halit Sokak, Bey Sokak ve Beyhamam Sokak üzerinden irdelenen çalışmada Halit Sokak özelinde yapılan pilot çalışma ile korumadaki eksiklikler, koruma sorunları ve sebepleri incelenerek; korumada öncelikler bağlamında bir koruma anlayışı için öneriler geliştirilmiştir.

Anahtar Kelimeler: Tokat Evleri, Sivil Mimari, Sokak Sağlıklaştırma, Koruma

\section{Proposal Of Conservation Approach In Traditional Housing Areas: Traditional Tokat Houses}

\begin{abstract}
The fact that historical cities, which are important parts of cultural heritage, have witnessed various periods throughout the history has made these cities important settlement centres. With its historical and cultural diversity, the city of Tokat has managed to conserve its original identity. Monumental buildings and examples of civil architecture in Tokat form the most fundamental cultural core of the city within the diversity of different periods. A sampling have been made towards a conservation approach over a street consisting of traditional house fabric of the city in the context of identified conservation problems and values through the evaluation of detailed documentation and analysis works for traditional Tokat Houses. A holistic evaluation, conservation and management approach could not be developed at city scale. The conservation approach only included make-up applications in front facades of the
\end{abstract}

Bu çalışma, birinci yazar tarafından ikinci yazar danışmanlığında tamamlanmış olan, "Tokat Kenti Geleneksel Konut Dokusunun Koruma Bağlamında Irdelenmesi: Halit Sokak, Bey Sokak, Beyhamam Sokak” adlı yüksek lisans tezinden yararlanılarak hazırlanmıştır.

${ }_{1}$ Arş. Gör., Mimar Sinan Güzel Sanatlar Üniversitesi, Mimarlık Fakültesi, Mimarlık Bölümü

2 Prof. Dr., Mimar Sinan Güzel Sanatlar Üniversitesi, Mimarlık Fakültesi, Mimarlık Bölümü

*ilgili yazar/ Corresponding author: dilaragokcen@hotmail.com

Gönderim Tarihi: 13.09.2019

Kabul Tarihi: 24.12.2019 
houses under the disguise of rehabilitation, without defining priority areas for conservation in terms of durability and values of the houses through the use of detailed inventory, evaluation and analysis. Located in the traditional house fabric of Tokat city; Halit Sokak, Bey Sokak and Beyhamam Sokak examined in this study, Halit Sokak in the pilot study carried out in the deficiencies of conservation, conservation problems and reasons are examined; recommendations have been developed for a conservation understanding in the context of priorities in conservation.

Key Words: Tokat Houses, Civil Architecture, Street Rehabilitation, Conservation

\section{GiRiş}

Konut/Ev kavramları insanın en temel ihtiyaçlarından biri olan barınma intiyacı doğrultusunda anlamlanarak şekillenmiştir. Yaşamsal pek çok parametre ile ilişkilendirilerek insana ait pek çok değerin madde ile ilişkisinin kurularak somutlaştığı ve bunun da somut bir karşılığı olan mimari üretimler, yaşamsal parametrelerden doğan ve zamanla dönüşen kültürel birikimlerin yansımasıdır. Bir kentin, bölgenin ve ülkenin kültürü o yerde yaşayan insanlara ait bilgiler barındırır. Kentin fiziksel verilerinin doğal olarak oluşturduğu özellikler ve o yerde yaşayan insanların zaman içerisinde gelişen sosyo-kültürel ve sosyo-ekonomik bileşenleri kentin kimliğini oluşturan etkenlerdir. Kentte tarihsel süreç içerisinde oluşan soyut ve somut kültürel mirastaki değişim ve dönüşümler içinde bulunulan döneme aktarılır. Geleneksel dokular ve bu dokularda yer alan geleneksel konutlar bu aktarımın önemli bir parçasıdır. Somut olmayan kültürel mirasın sosyal yaşantı içinde nesilden nesile aktarımı -gündelik yaşamın bir parçası olması sebebiyle- kendiliğinden ve süreçten beslenirken, kentin küçük ya da büyük bir parçasının sahip olduğu somut kültürel miras öğesinin korunarak muhafaza edilebilmesi için konu ile ilgili geliştirilecek koruma yaklaşımlarına intiyaç duyulmaktadır.

Tokat kenti tarihin farklı zaman dilimlerinde pek çok medeniyet ile bütünleşmiş, bu medeniyetlerin oluşturduğu kadim kültürler ve kimlikler ile var olmuş bir kenttir. Bu çalışmaya konu olan Tokat geleneksel evlerinin mimari özelliği bölge iklimine, malzeme kaynaklarına ve deprem risklerine en uygun malzeme olan ahşap malzeme ile kurgulanarak çözümlenmiş Osmanlı dönemi yaşam kültürüyle biçimlenmiş "Osmanlı evi/Türk evi" olarak tanımlanabilecek niteliğe sahip konutlar olduğu görülmektedir. Günümüze yalnızca 19.yy ve sonrası geleneksel konut örnekleri ulaşabilmiş olan Tokat kenti, özellikle Anadolu Selçukluları ve Osmanlı İmparatorluğu dönemlerinde uluslararası bir ticaret kenti olma özelliği kazanmıştır. Bu dönemlerde kent içinde pek çok sayıda mimari eser inşa edilmiştir. Kentte günümüze ulaşan geleneksel konutlar, ilk yerleşim olarak Tokat Kalesi etekleri, Sulusokak ve yakın çevresinde yoğunlaşmıştır. Geleneksel konut dokusunun özgün örneklerinin görülebildiği bir diğer alan ise Behzad Deresi mevkiinde Tokat Saat Kulesi yakın çevresindeki yerleşimlerdir.

Tokat kentinde geleneksel konut dokusunun korunmasına yönelik uygulanan kentsel koruma yaklaşımı sokak ölçeğinde "Sokak Sağıklaştırma Çalışmaları" adı altında yapılmıştır. Sokak sağlıklaştırma çalışması yapılan; Halit Sokak, Bey Sokak, Beyhamam Sokak, kent içinde doku ile beraber dikkate alınarak değerlendirilmiş bir koruma yöntemi olarak örneklendirilmiş uygulamalardır. Tokat evleri için koruma bağlamı bu başlık altında gerçekleştiği için sokak sağlıklaştırma çalışmalarının hangi yasal, yönetsel sınır ve çerçevelemeler içinde yer aldığına değinmek gerekliliği duyulmaktadır. Sokak sağlıklaştırma çalışmalarının proje ve uygulamalarına ilişkin usûl ve esaslar Kültür ve Turizm Bakanlığı tarafından hazırlanan yönetmelikle 
belirlenmektedir. Sokak sağlıklaştırma uygulamalarının teknik şartnamesi Kültür ve Turizm Bakanlığı bünyesinde düzenlenip hazırlanmasına rağmen, uygulama alanında herhangi bir yasal düzenleme olmadığı için yerel yönetimler ve il özel idareler tarafından yürütülen projeler farklılık göstermektedir. Mevcut projeler incelendiğinde Kültür Varlıklarını Koruma Bölge Kurulu tarafından alınmış bakım ve basit onarım kararları olarak gerçekleştirildiği, belediyeler tarafından yapılan projelerin ise daha farklı olduğu görülmektedir (Ünver, 2017, s. 97-98 ). 2863 sayılı Kültür ve Tabiat Varlıklarını Koruma Kanunu'nda yer alan tanımında; "Sokak sağlıklaştırma proje ve uygulamaları, kentsel sit alanları ve koruma alanlarında, korunması gerekli taşınmaz kültür varlıkları ile sokaktaki diğer yapıların özgün sokak dokusunu tanımlayan tüm öğelerle birlikte korunması ve belgelenmesine yönelik rölöve, restitüsyon, restorasyon, kentsel tasarım projeleri ile mühendislik dallarında yapılması gereken her türlü proje ve bunların uygulamalarıdır." şeklinde ifade edilmiştir. Sokak Sağlıklaştırma Projesi, 21/7/1983 tarihli ve 2863 sayılı Kültür ve Tabiat Varlıklarını Koruma Kanunu kapsamında belirlenen kentsel sit alanları ve koruma alanlarında, yapılan projelendirme yaklaşımıdır. ${ }^{3}$ Sokak sağlıklaştırma uygulamalarının yürürlükteki sınır ve çerçevelemeleri nedeniyle Tokat kenti içindeki üç sokakta bulunan konutların -Halit Sokak, Bey Sokak, Beyhamam Sokak- koruma uygulama çalışmaları ile düşük nitelikte, yalnızca kısa vadede korunması gerçekleşmiştir. 2004 yılında Halit Sokak, 2011 yılında da Bey Sokak ve Beyhamam Sokak için gerçekleştirilen Sokak Sağlıklaştırma çalışmaları yerel yönetimlerin bünyesinde konutların ön cephesi öncelik alınarak, basit bakım onarım kararları ile uygulamaya geçirilmiştir. Tokat kenti için sokak sağılılaştırma çalışması yapılan bu üç sokak özelinde, mevcut uygulamaların eksikleri de dikkate alınarak, geleneksel konutların bulunduğu sokak ve dokularda yer alan konutlar için uygulanabilir sistematik bir çalışma ile korumada öncelik belirleme yöntemi geliştirilmesi gerekli görülmektedir. Bu yöntem ile koruma uygulaması yapılacak olan geleneksel konutların bulunduğu tarihi sokaklarda nitelikli konutların uzun vadede somut kültürel miras örnekleri olarak gelecek nesillere aktarımı sağlanacaktır.

Bu çalışmada, Tokat kenti örneği üzerinden, kent içindeki geleneksel konut dokusunda yapılan -hem alan ölçeğinde hem de yapı ölçeğinde- güncel belgeleme, çözümleme ve değerlendirme çalışmaları ile tarihi süreç içerisinde koruma bağlamında eksiklikleri, koruma sorunlarını ve bunların nedenleri incelenerek çözüm önerileri sunacak bir koruma yaklaşımı oluşturmak amaçlanmıştır. Tokat kenti geleneksel konut dokusunun bir bölümünü oluşturan ve daha önce koruma çalışmaları ile müdahale edilmiş; Halit Sokak, Bey Sokak, Beyhamam Sokak'ta alan ölçeğinde sokak sağlıklaştırıması incelenerek, yapı ölçeğinde geleneksel konut örneklerinin mimari özelliklerinin ve koruma sorunlarının belirlenmesi, belgelenmesi ve çözümlenmesi yapılmıştır. Bu bağlamda pilot çalışma alanı olarak seçilen Halit Sokak'ta yer alan öncelikli koruma yaklaşımı değerlendirmesi için örnek olabilecek; nitelikli olarak görülmüş ve seçilmiş 7 konut örneği üzerinden geliştirilen öneriler değerlendirilmiştir. Bu sokakların araştırma ve inceleme için çalışmaya seçilme ölçütü Tokat Kenti' ndeki sokak sağlıklaştırma çalışmalarının bu sokaklar üzerinde tatbik edilmiş olması olup, pilot çalışma alanının da Halit Sokak olarak seçilme nedeni ise, diğer sokaklara göre alan ölçeğinde ve yapı ölçeğinde konutların daha farklı ve çeşitli bozulma biçimlerine sahip olmasıdır.

Konu ile ilgili olarak mevcut literatür taramalarında yapılmış çalışmalarda, bir koruma yaklaşımı olarak görülen sokak sağlıklaştırma proje ve uygulamalarının kentsel ya da sosyal bağlamda ele alındığı görülmüştür. Bu bağlamda görülen eksiklik ile araştırmanın sorunsalı, geleneksel konut dokusu ve bu doku içerisinde yer alan

\footnotetext{
${ }^{3}$ http://www.kulturvarliklari.gov.tr/TR,51992/kultur-varliklari-ihaleyonetmeligi-25072013-tarih-ve-2-.html
} 
konutlar ile ilgili bir koruma yaklaşımı geliştirebilmek için sokak sağlıklaştırma çalışması yapılmış bir sokakta alan çalışması yapılarak konutların korumada öncelik sırasının belirlenmesi; mevcut durumun belgelenerek gerekli çözümleme ve değerlendirilmelerin yapılması,ortaya çıkan koruma yaklaşımının sonraki çalışmalar için örnek oluşturmasıdır. Geleneksel doku içerisindeki konutların kültürel mirasın önemli bir parçası olduğunun ortaya konarak tespit edilmesi, makro ölçekten mikro düzeye kadar mevcut dinamikleri içerir sistematik bir yöntem doğrultusunda geleneksel konut mimarisinin hakim olduğu sokaklarda geliştirilecek olan koruma yaklaşımı gerekliliğinin vurgulanması araştırmanın en temel hipotezidir.

\section{ALANIN ÖZELLiĞí}

\subsection{Tokat geleneksel konut dokusu}

Tokat kenti vakıf gelirleri ile, Türk-İslam kültürü esaslarına göre ilk defa Danişmentliler tarafından imar edilmiştir. Danişmentliler'in ilk imar faaliyeti Tokat Kalesi içindeki Melik Gazi Camisi ve sonrasında da Garipler Camisi inşası ile başlamıştır (Aksulu, 1999: 343). Yine yakın çevrede bulunan Ulu Cami ise Selçuklular'ın Danişmentliler yerleşimi içinde bulunan ilk imar çalışmaları olarak görülmektedir. Sonrasında ise bu bölgede yapılan pek çok yapı ile Tokat Kalesi etekleri ve yakın çevresi ilk yerleşim yeri olarak konumlanmaya devam etmiştir. 1930 yılında Tokat'ın İmar Planı'nın yapılması için bir takım çalışmalara başlanmış olup ilk kent haritası 1934 yılında yapılmıştır. 1948 yılında ikinci imar planı olarak 1/5000 ölçekli Tokat İmar Planı yaptırılmıştır. 1967 yılında üçüncü imar planı yapılmış ve kent merkezden uzakta yeni yerleşmelerin olduğu bölgelerde yoğunlaşmıştır (Kuntay, 1982, s. 10). Tokat kentinde yapılan kentsel ölçekteki koruma çalışmaları ilk olarak 1981 yılında Kültür Bakanlığı Gayrimenkul Eski Eserler ve Anıtlar Yüksek Kurulu Başkanlığı tarafından alınan 14.11.1981 tarih ve A3218 sayılı kararı eki 1/5000 ölçekli "Tokat İmar Planı" nın kabulü ile başlamıştır. Sonrasında, Eski Eserler ve Müzeler Genel Müdürlüğünün 14.09.1984 tarih ve 379 sayılı (Kültür Varlıkları ve Müzeler Genel Müdürlüğü arşivinden), "Tokat il merkezi, kentsel sit alanı ve korunması gerekli taşınmaz kültür ve tabiat varlıklarının tespiti" kararının diğer bir eki olan 1/1000 ölçekli hali hazır haritalarda "Taşınmaz Kültür Varlığı" olarak tescil edilen yapılar işaretlenmiş, bölgesel sınırlar çizilerek sit alanları belirlenmiştir.

Tokat'ta geleneksel Osmanlı/Türk evlerinin günümüze ulaşabilen en erken örnekleri 19 yy. örnekleridir. Bu konutlar Kale eteklerinde ve Behzat Deresi kıyılarında yoğunlaşmaktadır. Bu evlerden 124'ü Taşınmaz Kültür ve Tabiat Varlıkları Yüksek Kurulunca 14.09.1984 gün ve 379 sayılı kararı ile tescillenmiştir. Ancak evlerden bir kısmı tescilden düşürülmüş olup günümüzde Tokat'ta 118 adet tescilli ev bulunmaktadır (Akyüz vd., 2010, s.1-492). Alanda bunların dışında tescile önerilebilecek nitelikte konutların bulunduğu gözlenmiştir. 


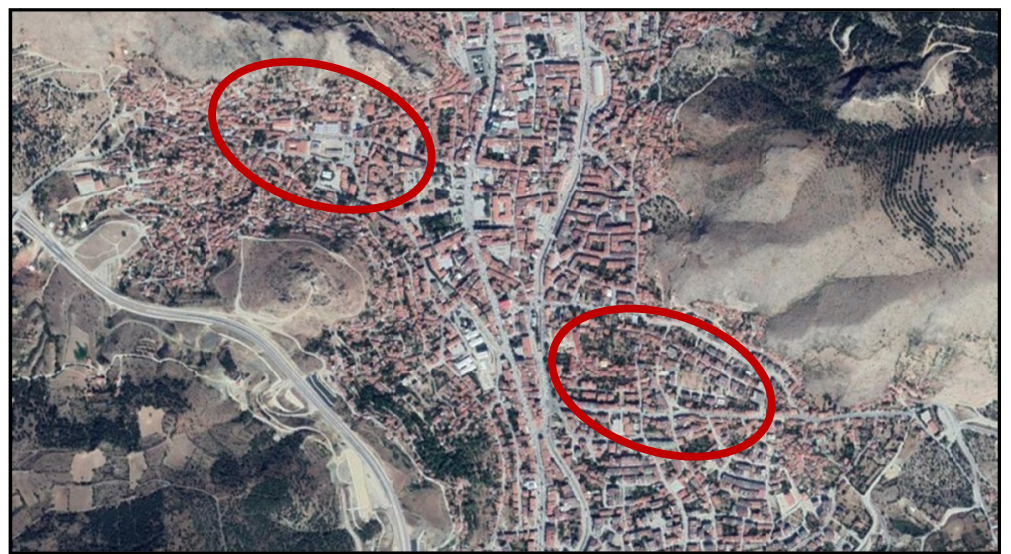

Şekil 1. Halit Sokak, Bey Sokak, Beyhamam Sokak hava fotoğrafı (Google Earth ${ }^{4}$ )

1984 yılında 1/1000 ölçekte çizilen Koruma Amaçlı İmar Planı'nda tescilli yapılar işlenerek sit alanları belirlenmiştir. Planda 2. ve 3. derece kentsel sit alanları mevcuttur. Bununla birlikte çerçeve sit koruma alanı da mevcuttur. Sokak sağlıklaştırma çalışmaları yapılan Halit Sokak, Bey Sokak ve Beyhamam Sokak'ta koruma altındaki sokaklar olarak belirlenmiştir. Halit Sokak, çerçeve sit koruma alanı içerisinde iken, Bey ve Beyhamam Sokak 3. derece kentsel sit alanı sınırları içerisindedir.

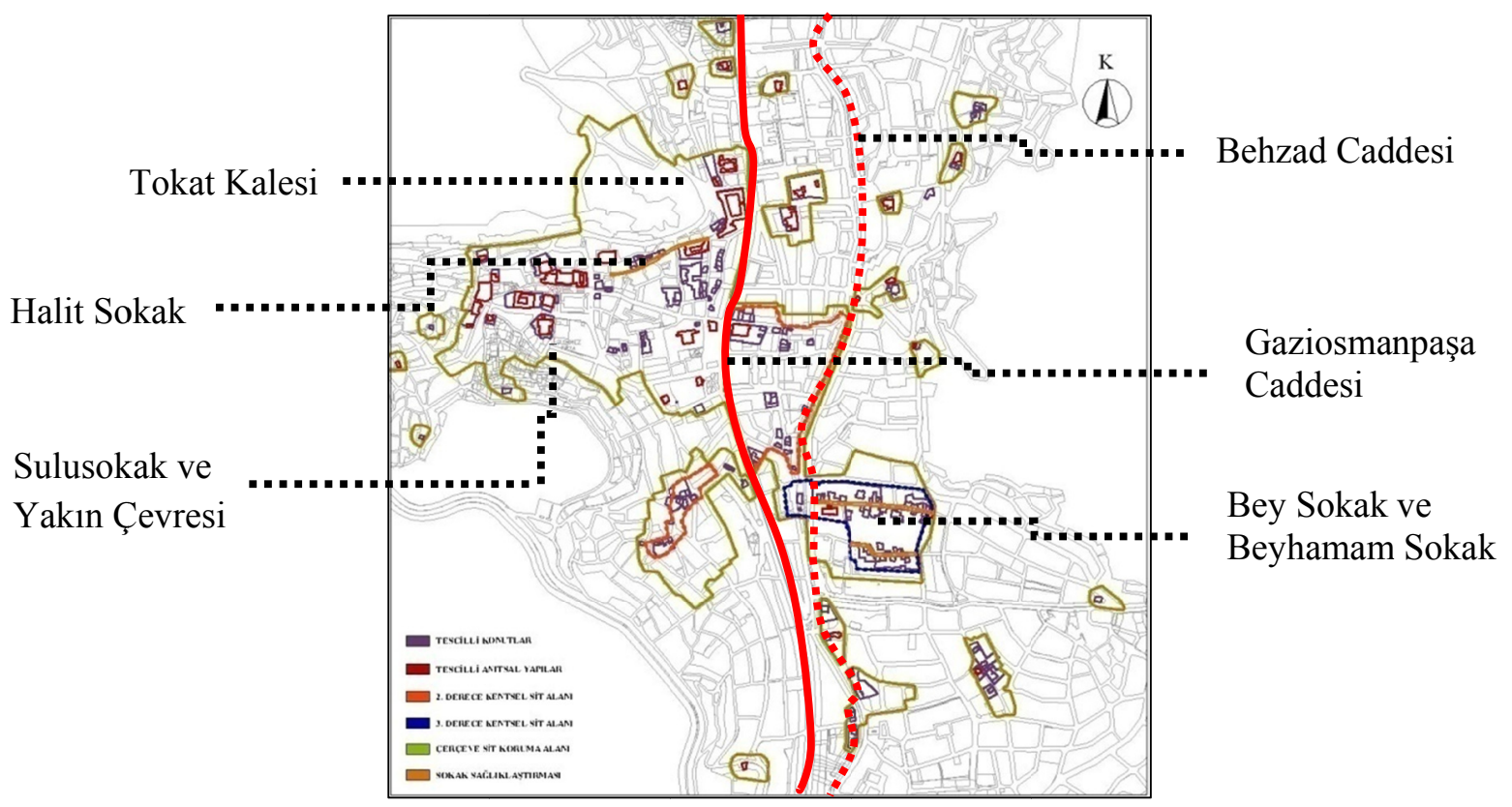

Şekil 2. Tokat kenti sit alanları (Düzenlenmiş, Tokat Belediyesi arşivi)

Tokat'ta geleneksel konut dokusunun bulunduğu sokaklardaki konutların yerleşimi çoğunlukla bitişik nizam olup, bahçe arka cephede yer alırken, bitişik nizamda olmayan, serbest yerleşmiş konutların ise girişinin bahçe tarafından olduğu görülmektedir. Geleneksel Tokat evleri genellikle iki veya üç katlıdır. Zemin katlar genel hizmetlere ayrılmıştır. Zemin katların tabanı taş döşemeli olup "taşlık" olarak adlandırımaktadır. Zemin katta wc, kiler, ambar, depo gibi mekânlar bulunurken, büyük ve küçük ocaklar, fırın ve "iş evi" de bu katta yer almaktadır. Evlerin üst katları

\footnotetext{
${ }^{4}$ 27.08.2018 görüntü tarihli Google Earth hava fotoğrafı
} 
çoğunlukla günlük hayatın geçtiği ve yaşama mekânlarının olduğu katlardır. Diğer katlara göre üst katlar çok daha iyi aydınlatılmıştır. Çal Tokat evlerini üç plan tipinde tanımlamıştır. a-İki yüzü odalı iç sofalı plan tipi, b-Üç tarafı odalı dış sofalı tip, c-Dış ve köşe sofalı tip (Çal, 1988,s. 30). Halit Sokak, Bey Sokak ve Beyhamam Sokak'ta incelenen ve tipolojisi çıkarılan evler sofa oda konumuna göre dış sofalı, iç sofalı ve sofasız olarak tanımlanmıştır. Plan ve cephe tipoloji çalışmaları aşağıda yer almaktadır.

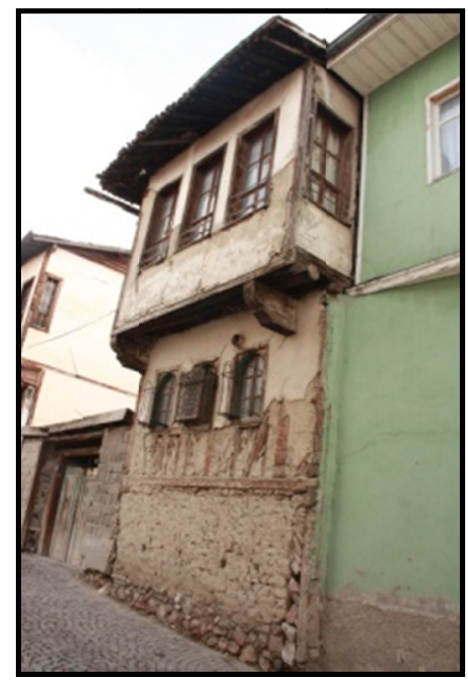

Şekil 3. Bir konut cephesi/ Bey Sokak

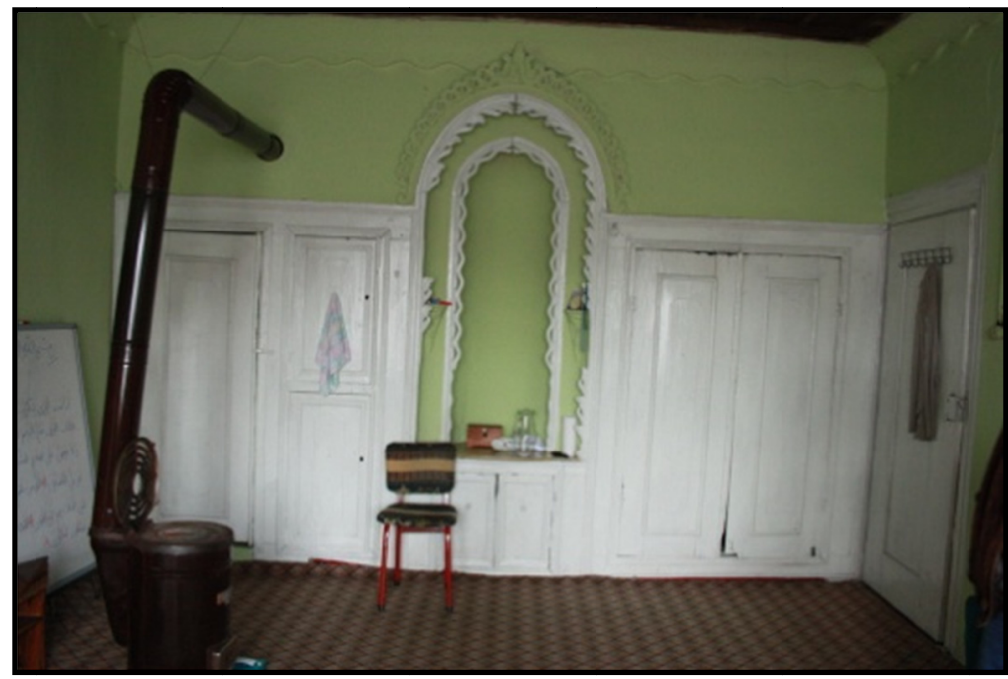

Şekil 4. Üst katta yüklük/ Bey Sokak (Yazar arşivi, 2013)

Geleneksel Tokat evlerinde cephe dikkate alınarak yapılan tipoloji çalışmalarında farklı özelliklerdeki çıkmalar cephenin belirleyici elemanı olarak görülür. Konutların cephe tipleri; tek çıkmalı, çift çıkmalı, cephe genişliğince çıkmalı olarak tanımlanmıştır. Tokat evleri'nde cephelerde sıva dışında günümüze ulaşmış farklı bir cephe malzemesi örneğini görmek mümkün değildir. Konutların pek çoğunun cümle kapıları kanatıdır. Bahçe, bağ ve avlu kapıları ise ahşap olup yük hayvanlarının girebileceği yükseklik ve genişlikte yapılmıştır (Yavi, 1986, s.101). Geleneksel Tokat evlerinin yapım sistem ahşap çatkılarla kurulan konstrüksiyon aralıklarının kerpiçle doldurulmasıyla oluşan "Hımış" tekniğidir (Yavi, 1986, s. 99). Taş temel üzerine ahşap çatkı arrası kerpiç dolgu esas malzeme olan bu teknikte ahşap çatkı kurulduktan ve kerpiç dolgu geçirildikten 
sonra iç yüzeyler samanlı çamur sıva üzeri alçı, dış yüzeyler kıtıklı kireç sıva ile kapatılmaktadır (Çal, 1988, s. 32).

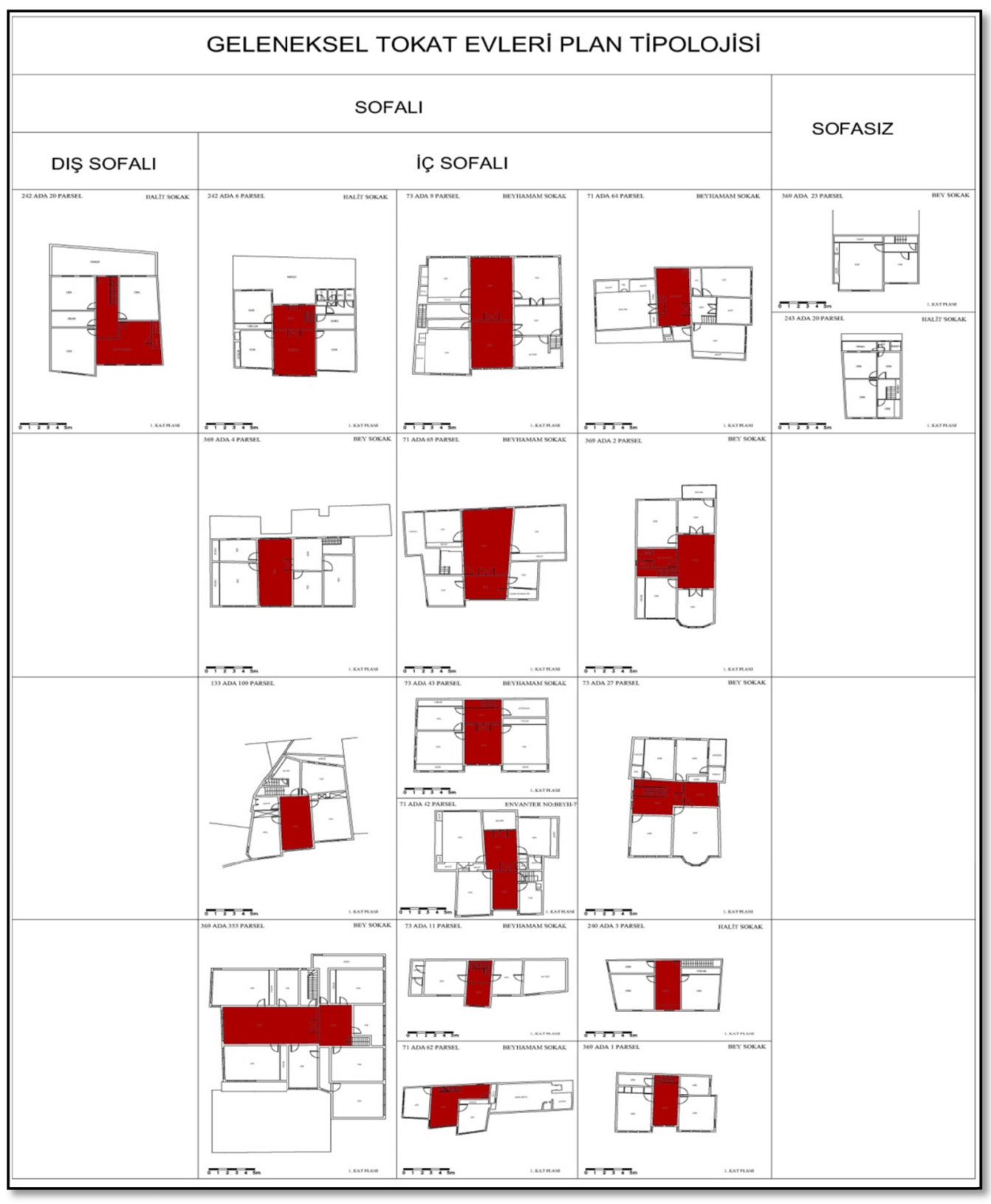

Şekil 5. Geleneksel Tokat evleri plan tipolojisi (Yazar tarafından hazırlanmıştır.) 


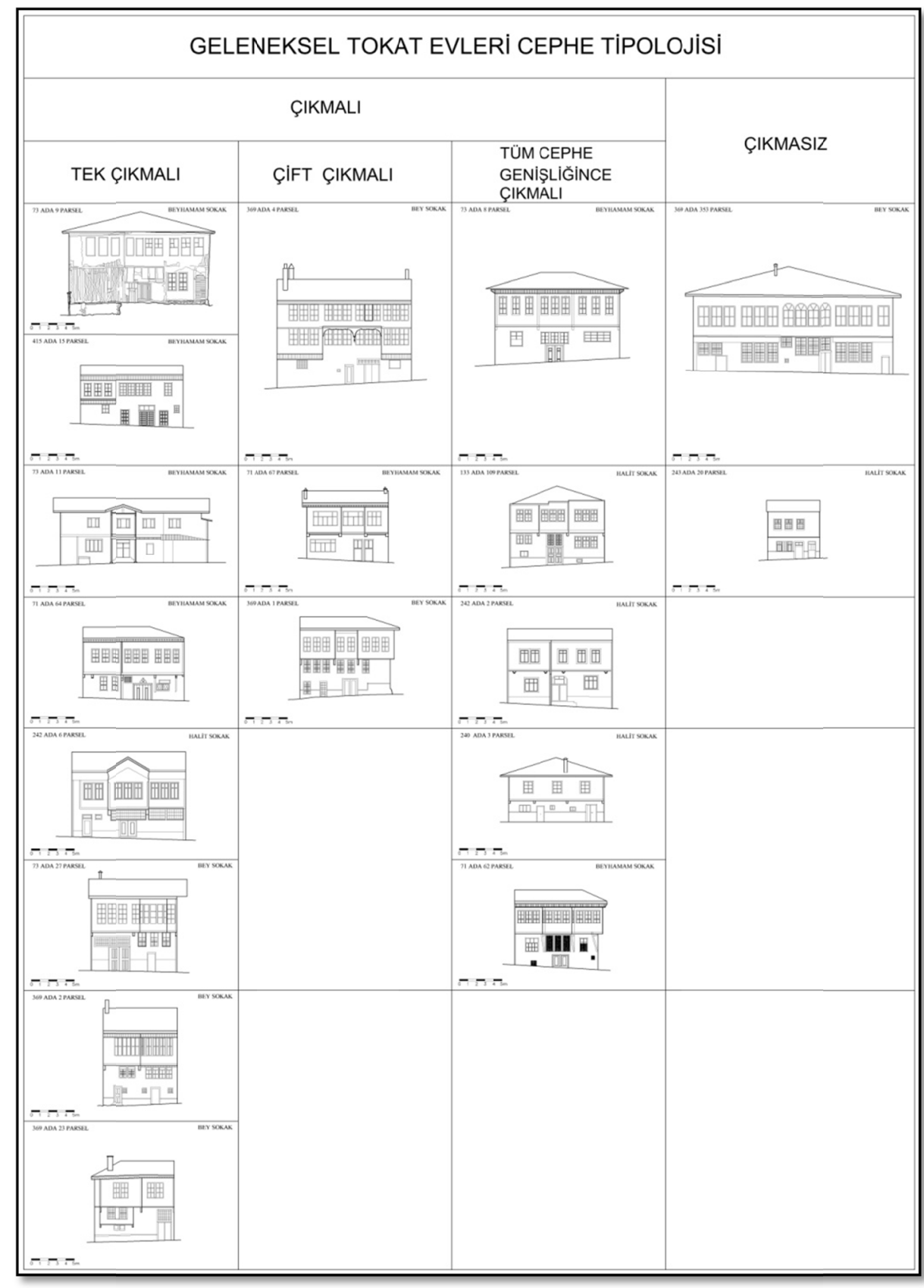

Şekil 6. Geleneksel Tokat evleri cephe tipolojisi (Yazar tarafından hazırlanmıştır.)

\section{TOKAT KENTI GELENEKSEL KONUT DOKUSUNUN ANALIIZi}

\subsection{Halit sokak}

Halit Sokak Tokat kentinin ilk yerleşim merkezinde yer alan konut dokusunun oluşturduğu sokaklardan birisi olup kentteki gayrimüslimlerin büyük bir kısmının bu sokakta yaşadığı kaynaklarda yer almaktadır (Aktüre, 1978, s.159). Sokakta günümüze 
ulaşmayan fakat gayrimüslimler için inşa edilmiş olan iki kilisenin bulunduğu da kaynaklarda geçmektedir (Anonim, 1984, s. 7085).

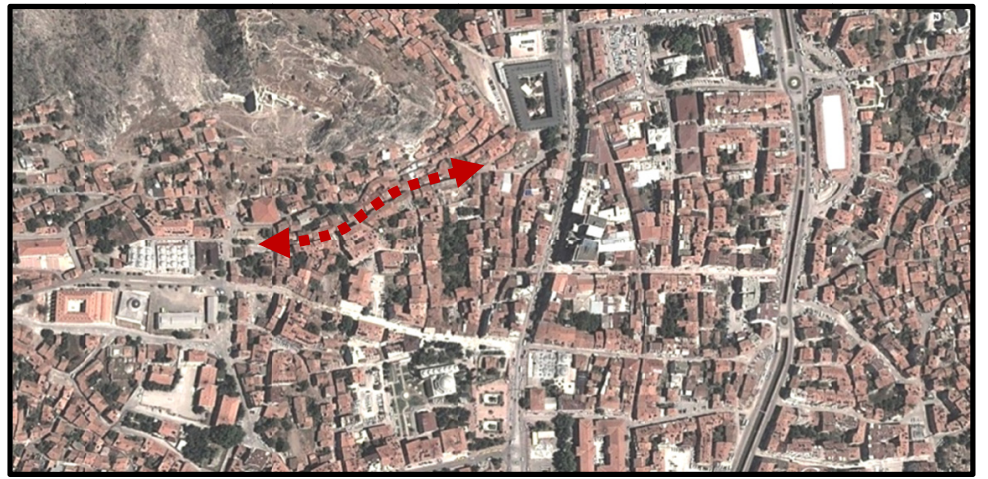

Şekil 7. Halit Sokak konumu (Google Earth)

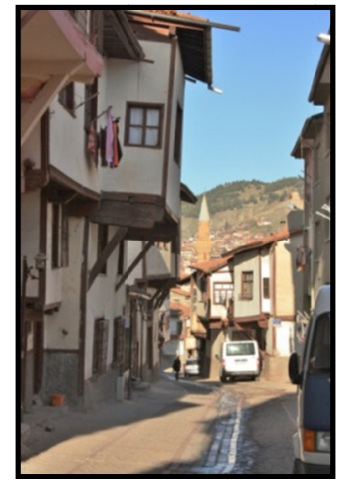

Şekil 8. Halit Sokak (Yazar arşivi, 2016)

Arslanyan "Hemen şu sağ tarafta Sulusokak'a açılan aralık Yahudi malhallesiydi. Bu bir çıkmaz sokaktı. Yedi sekiz Yahudi ailesi bu mahallede iç içe yaşardı"(Arslanyan, 2012, s.88) olarak alanı tanımlamıştır. Sokak boyunca 41 adet yapı bulunmaktadır. Tarihi Yazmacılar Hanı bu yapılardan biridir. 1882 yılında inşa edildiği düşünülen tescilli han ile beraber sokak üzerinde bulunan bir diğer tescilli anıtsal yapı da Kabe-i Mescid Camisi'dir.

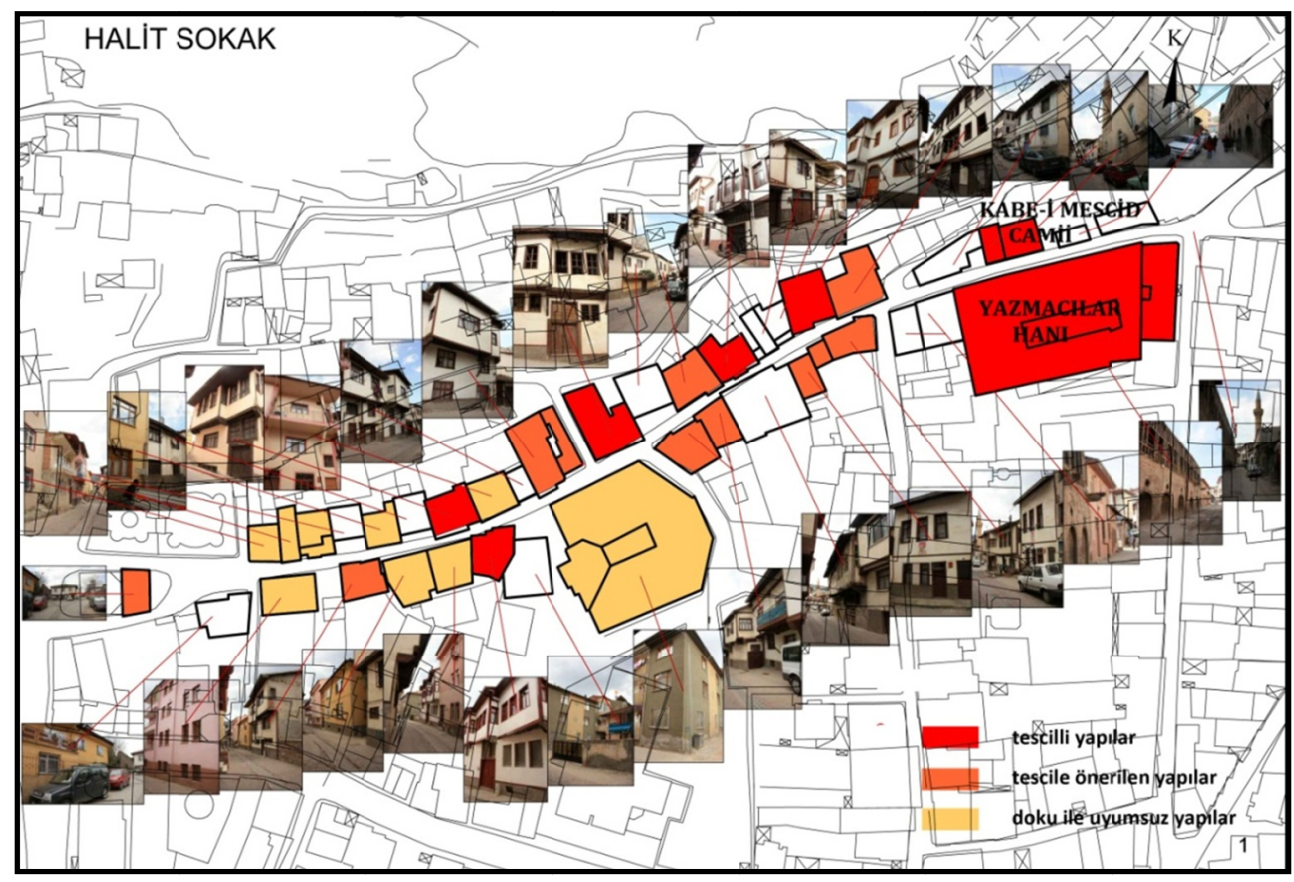

Şekil 9. Halit Sokak genel analiz

Sokak üzerindeki diğer yapı grubunun tamamı konut olarak kullanılmakta olup mevcutta 5 konut tescilli olarak yer alırken, yapılan iç-dış gözlem ve araştırmalar sonucunda sokak üzerinde yer alan, tescile önerilebilecek yapıların da varolduğu görülmüştür. Geleneksel konut dokusuna aykırı olarak, mevcut doku ile uyumsuz olduğu görünen yapı grubu dışında kalan konutlar, tescile önerilebilecek kadar nitelikli olmayıp, dokuya uyumlu konut karakteri özelliği göstermektedir. 

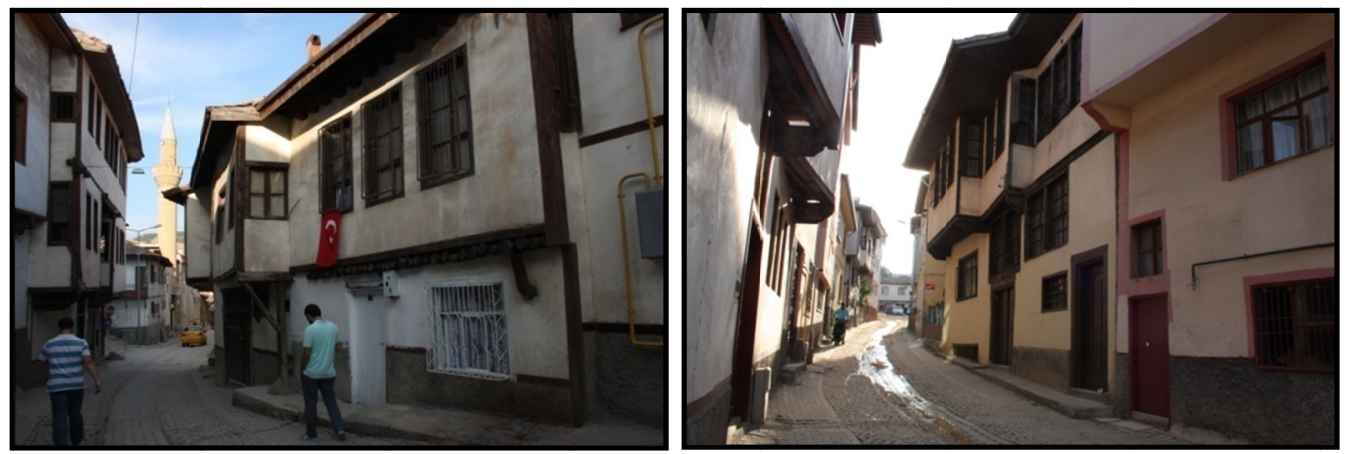

Şekil 10. -11. Halit Sokak (Yazar arşivi, 2016)
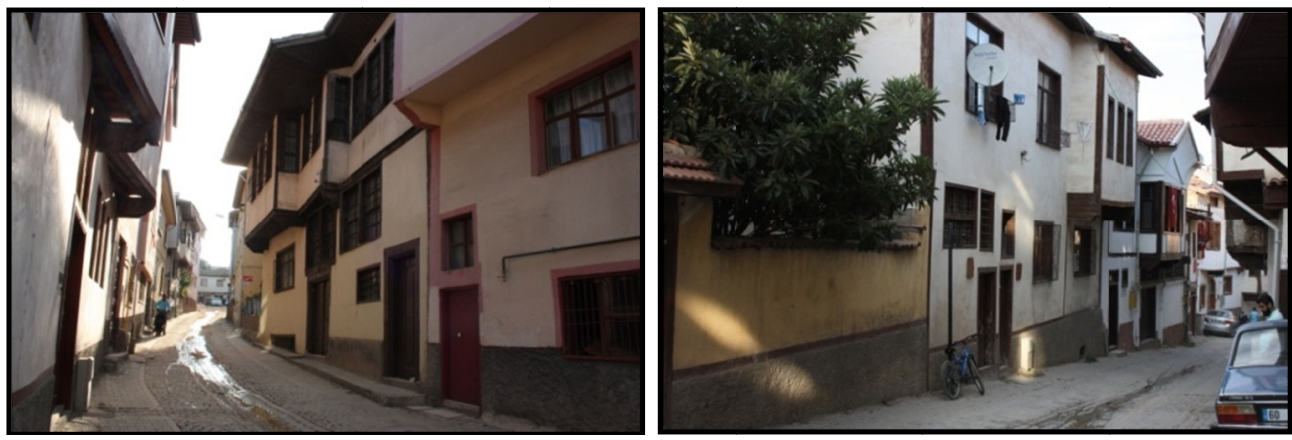

Şekil 12. -13. Halit Sokak (Yazar arşivi, 2016)

Sokak üzerinde bulunan konutların yapım tarihi bilinmemektedir, fakat benzerleriyle karşılaştırıldığında 19.yy sonlarına doğru inşa edildiği düşünülmektedir. Sokak genelinde yeni yapılaşmanın hakim olduğu Halit Sokak'ta geleneksel yapım sistemiyle inşa edilmiş nitelikli konut örnekleri de mevcuttur. Bu sokakta 2004 yılında "Sokak Sağlıklaştırma Projesi" ile ön cephe onarımıyla sınırlı bir koruma uygulaması yapılmıştır. Sokak üzerinde bulunan Yazmacılar Hanı, Kabe-i Mescid Camisi ve üst katı konut olarak kullanılan iki adet dükkanın dışındaki yapılar özgün kullanımı olan konut olarak kullanılmaktadır ve geleneksel konutların pek çoğu bir ve iki katlı iken, yeni yapılaşmalarda üç ve daha fazla kat bulunmaktadır. Halit Sokak'ta Yazmacılar Hanı, Kabe-i Mescid Camisi anıtsal yapı olarak, beş konutta sivil mimarlık örneği olmak üzere mevcutta yedi adet yapı tescillidir.

Konutlara giriş tüm konutlarda sokak cephesinden olup, vaziyet planı üzerinden konutların konumlanışı sokak-bahçe-konut, ya da sokak-konut-bahçe şeklinde değişiklik göstermiştir. Sokak üzerindeki geleneksel konutların plan özellikleri evi plan tipolojisine uygun iç sofalı plan tipindedir. Zemin kat daha çok mutfak, banyo,wc, iş evi, depo gibi birimlere ayrılmışken üst katlar yaşam birimleri olarak kurgulanmıştır. Konutlar iki veya üç katlıdır. Geleneksel konut cepheleri çıkmalı olup, çoğunluğu özgünlüğünü korumuştur. Yeni yapılaşmaların tamamı betonarme yapım sisteminde olup, geleneksel konutlar kentteki diğer geleneksel konutların yapım sistemi ile benzer özellikte olup ahşap karkas yapım sisteminin kullanıldığı görülmektedlir. Özgünlüğünü koruyan konut yoğunluğunun giderek azaldığı Halit Sokak'ta ikamet eden ev sahiplerinin sosyo-ekonomik düzeyi orta seviyede olmasına rağmen, kiracı olarak ikamet eden kullanıcıların gelir düzeyinin düşük seviyede olduğu alan çalışmasında gözlenmiştir. 


\subsection{Bey Sokak}

Soğukpınar Mahallesi'nde yer alan Bey Sokağı'nın dahil olduğu bölgenin tarihsel süreç içerisindeki gelişimini, günümüze ulaşabilmiş resmi kayıt ve belgelerden ulaşmak mümkündür. Bu belge ve kayıtlardan olan bazı şeriye sicillerinde Soğukpınar zimmî ve müslim olarak iki ayrı mahalle olarak kaydedilmiştir (Aktüre, 1978,s. 144). Bey Sokağı girişinde yer alan Tokat Mevlevihanesi'nin de ilk inşa tarihinin 13. yüzyıla kadar gittiği tahmin edilmektedir. Bey Sokak üzerinde bulunan Mevlevihane, Mevlevi Hamamı, Müftülüğe ait eğitim yapısı, Mevlevi Hamamı yanındaki tek katlı yapılar dışındaki tüm yapılar konut olarak kullanılmakta olup, 2011 yılında konutlara sokak sağlıklaştırma çalışması yapılmıştır. Bey Sokak'ta bulunan konutların çoğunlukla üç katlı olduğu görülmektedir. Sokakta 21 adet tescilli yapı bulunmaktadır.

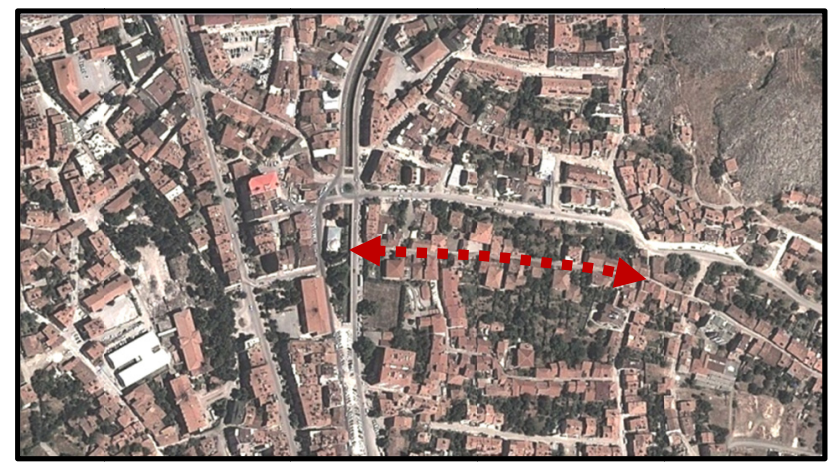

Şekil 14. Bey Sokak konumu (Google Earth)

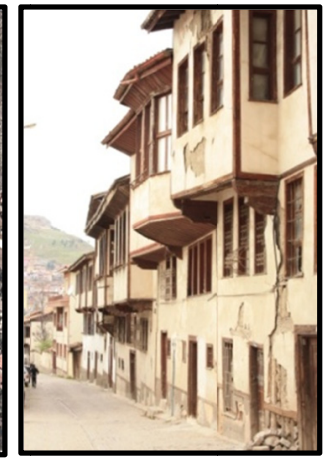

Şekil 15. Bey Sokak

(Yazar arşivi, 2013)

Bey Sokak'ta konutların vaziyet planı açısından konumlanışı sokak-bahçe-konut, sokak-konut-bahçe ya da sokak-bahçe-konut-bahçe şeklindedir. Çoğunluk olarak sokak-konut-bahçe olarak konumlanmış konutlara giriş sokak cephesindendir. Geleneksel konutların çoğunlukla iç sofalı plan tipindedir. Zemin katta mutfak, banyo, wc, iş evi, depo, odunluk gibi birimler bulunurken, üst katlarda yaşam birimleri yer almaktadır. Taş bir su basman üzerinde ahşap çatkı arası kerpiç dolgu malzeme ile oluşturan ahşap karkas yapım sistemine sahip geleneksel konutların cephelerinin her birinde çıkma görülmektedir. Bey Sokak'ta konutlardaki kullanıcıların genel olarak gelir seviyesinin ortalama düzeyde olduğu gözlenmiştir. Bey Sokak için konutlara en büyük tehdit konut sahiplerinin bu konutlarda yaşamamaları ve konutların aktif olarak kullanılmamasıdır. Bey Sokak, sosyal ve ekonomik nitelikler açısından geleneksel konut dokusundaki kullanıcıların gelir düzeyi en iyi sayılabilecek sokaklardan biridir. 

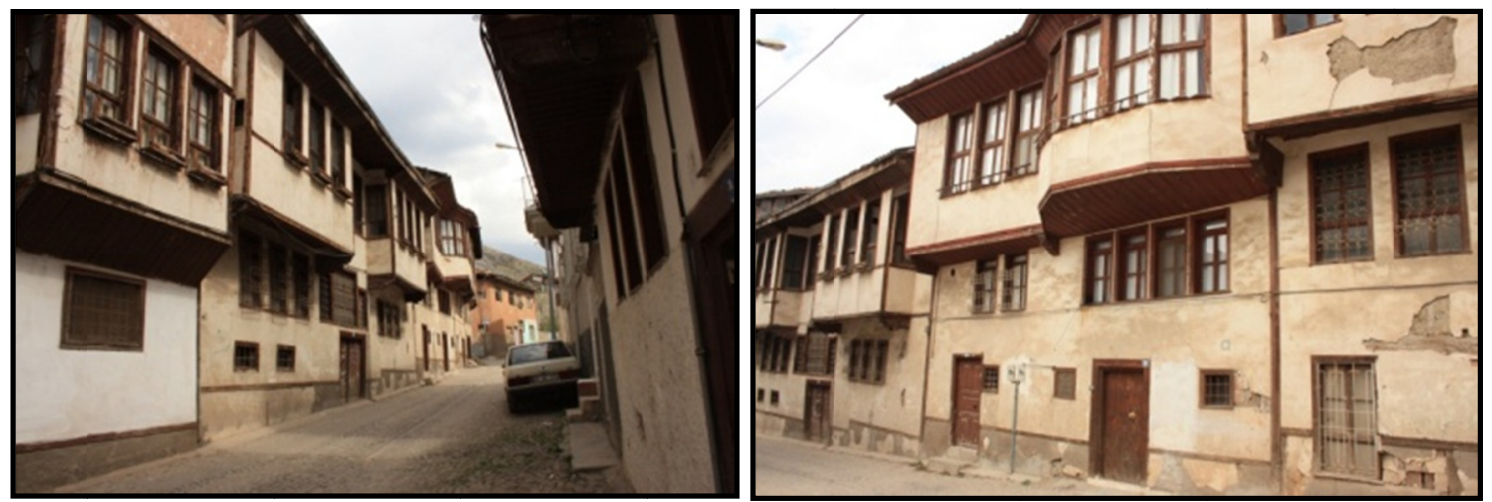

Şekil 16.-17. Bey Sokak (Yazar arşivi, 2013)

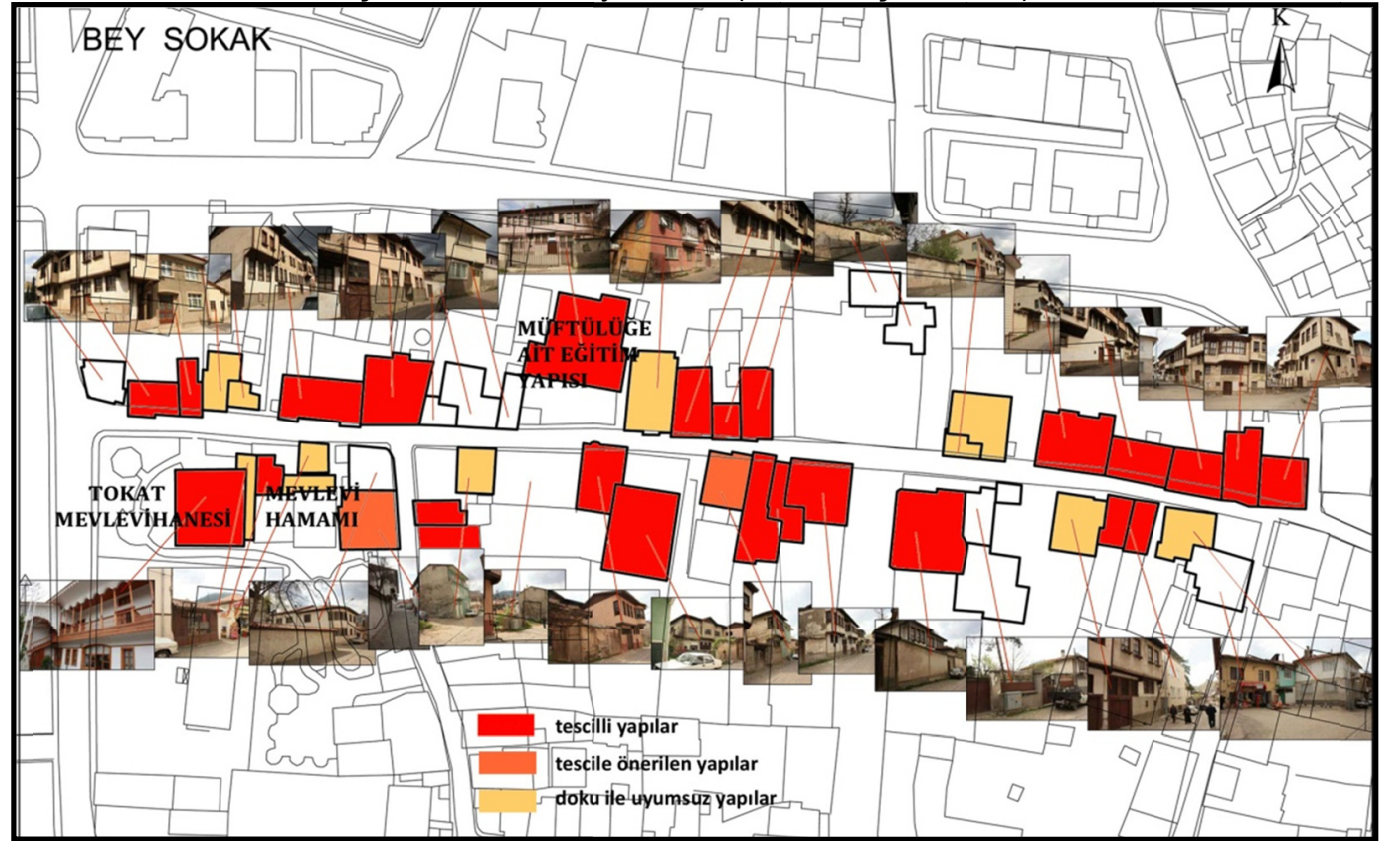

Şekil 18. Bey Sokak genel analiz

Bey sokak özelinde yapılan iç-dış gözlem ve araştırmalar sonucunda tescile önerilebilecek nitelikli yapıların da mevcut olduğu gözlenmiştir. Mevcut dokuya uyumsuz olan konut örnekleri sokak üzerinde yer alırken, aynı zamanda kat sayısı ve cephe düzeni açısından sokak silüetini bozmayacak şekilde uyum sağlayan, eski yapılaşmanın deformasyona uğrayarak yenilenmesi ile oluşan konut grubunun da yer aldığı görülmektedir.

\subsection{Beyhamam Sokak}

Tokat'ta inşa tarihi kitabesinden bilinen konutlardan biri Beyhamam Sokak'ta 73 ada 13 parselde yer alan Cevdet Erek Evi'dir. H. 1321/M.1903 tarihli bu konut diğer konutların tarihlendirilmesinde örnek oluşturabilir. Sokak üzerinde yer alan 1704 tarihli Mevlevihane ve hamam ile birlikte bütün oluşturan ve büyük çapta yenilendiği düşünülen Vakıf Evi 18.yy yapısıdır. Bu sokaktaki konutların bu iki yapının inşa tarihine göre 19.yy dan itibaren 20. yy başlarına kadar yapıldığı düşünülebilir. Konutların özgünlüğünü günümüze taşıdığı ve yeni yapılaşmanın az görüldüğü bu sokakta, 2011 yılında "Sokak Sağlıklaştırma Çalışması" yapılımıştır. 


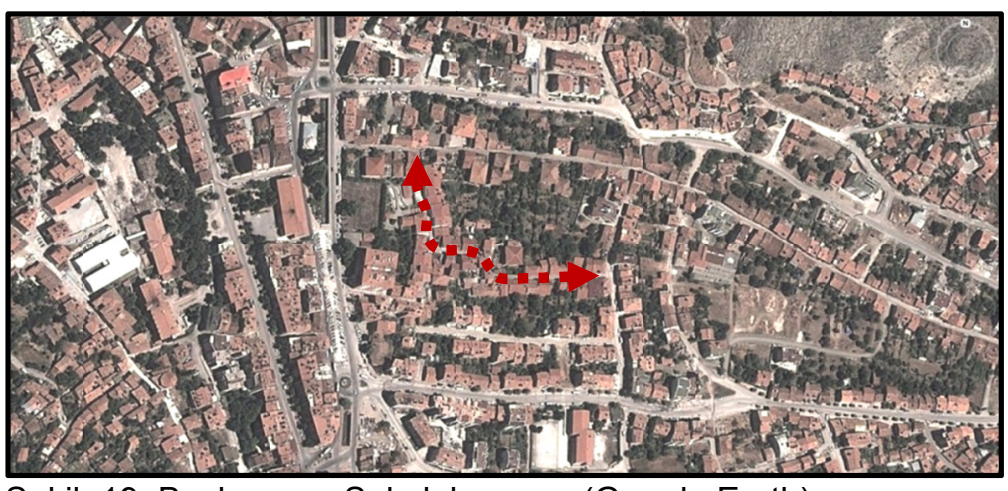

Şekil 19. Beyhamam Sokak konumu (Google Earth)

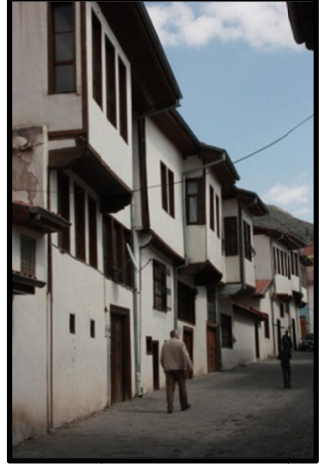

Şekil 20. Beyhamam Sokak (Yazar Arşivi, 2013)

Beyhamam Sokak'ta konutların vaziyet planına göre çoğunlukla sokak-konut-bahçe ilişkisi görülmektedir. Özgünlüğünü korumuş konutların Türk evi plan tipolojisine uygun diğer sokaklardaki konutlarla benzer şekilde iç sofalı plan tipindedir. Genellikle iki ya da üç kat olan konutların cephede çıkma biçimi özgün durumunu korurken genel olarak cephedeki kapı pencere gibi yapı elemanları özgün değildir. Sokak üzerindeki yeni yapılaşmalar betonarme yapım sistemi yapılmış iken geleneksel yapılar ahşap karkas yapım sistemi ile inşa edilmiştir. Beyhamam Sokak'ın sosyo-ekonomik durumu, konutlarda ikamet edenlerin konutun sahibi olması sebebiyle gelir düzeyi Halit Sokak ve Bey Sokak ile karşılaştırıldığında orta düzeydedir.

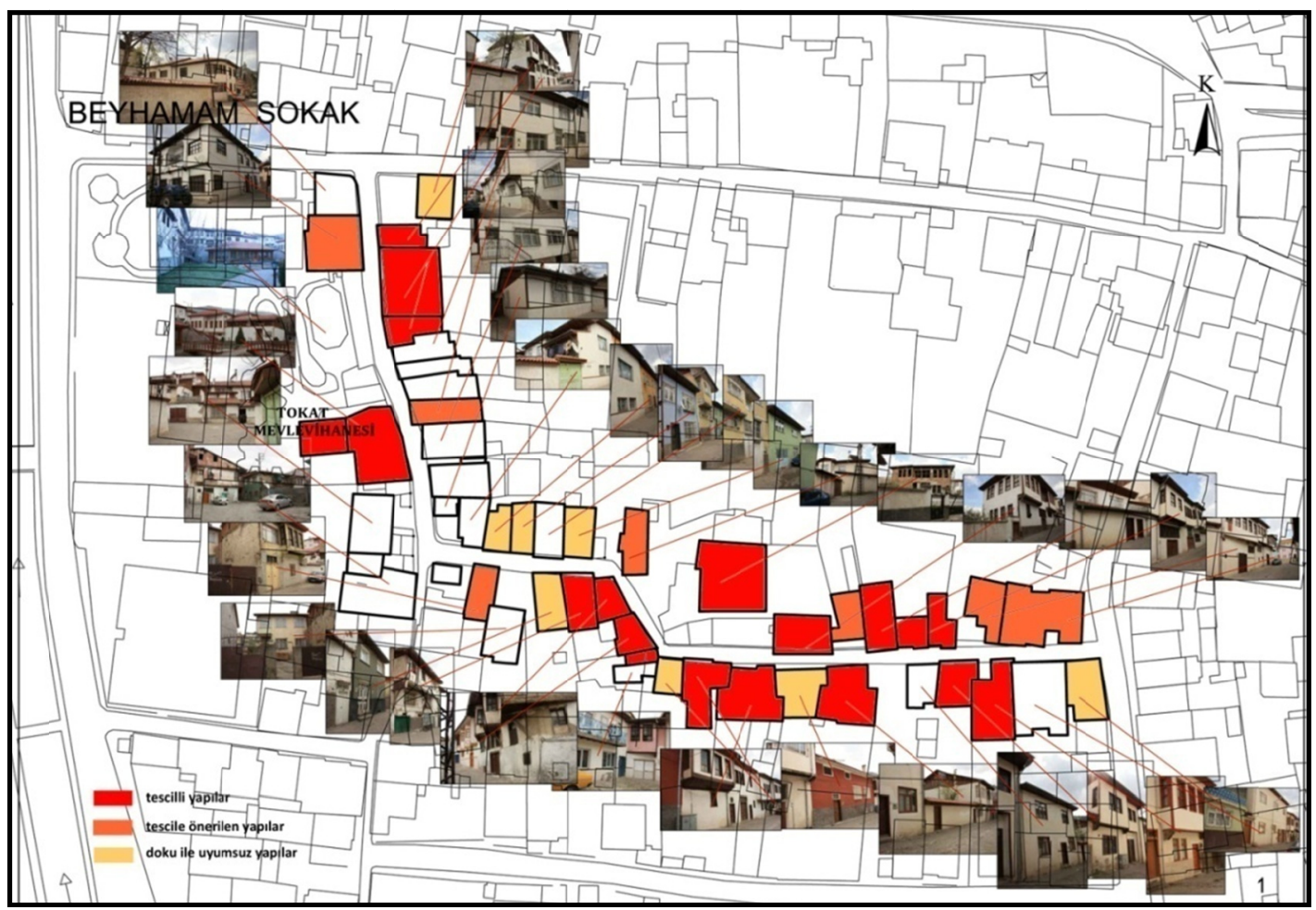

Şekil 21. Beyhamam Sokak genel analiz 

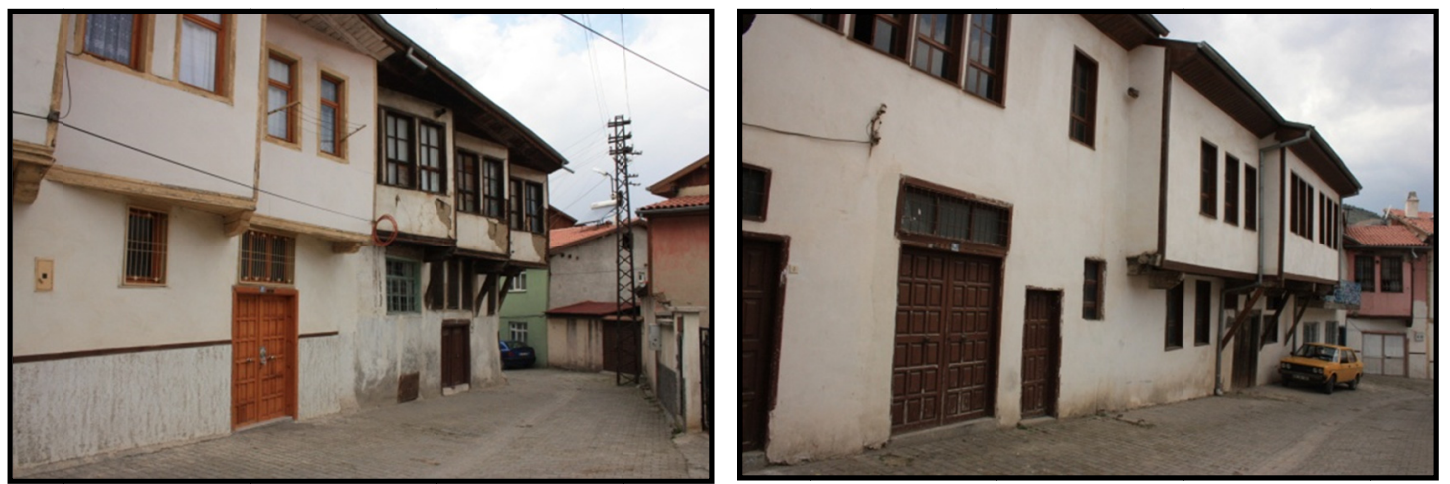

Şekil 22.-23. Beyhamam Sokak (Yazar arşivi, 2013)

Beyhamam Sokak'ta bulunan yapılardan müze olarak kullanılan Vakıf Ev ve dışındakilerin tamamının özgün kullanımı konuttur. Sokak üzerindeki yapıların tamamına yakını iki katlıdır. Sokakta çok katlı yapı bulunmamakla beraber yeni yapılaşmanın da geleneksel dokuya uyum sağlayacak şekilde kat sayısına sahip olduğu görülmektedir. Sokakta yer alan 18 yapı korunması gerekli taşınmaz kültür varlığı olarak tescillenmiştir. Beyhamam sokakta mevcut tescilli konutlara ek olarak, yapılan iç-dış gözlem ve araştırmalar sonucunda tescile önerilebilecek nitelikli yapılar tespit edilmiştir. Geleneksel dokuya uyumsuz konut örnekleri sokak üzerinde analiz çalışmasından yer alırken, eski yapılaşmanın zaman içerisinde yapısal ve fiziksel olarak bozulmalara uğrayarak cephe eleman ve malzemelerinin yenilenmesi ile oluşan; doku içerisinde sokak silüetini bozacak bir etki oluşturmayan ancak nitelikli olarak da görülemeyecek konut grubunun da yer aldığı görülmektedir.

\section{HALIT SOKAK, BEY SOKAK, BEYHAMAM SOKAK ILE ILGILI KORUMA SORUNLARI}

\subsection{Bozulma nedenleri}

\subsubsection{Doğanın oluşturduğu nedenler}

Kuzey Anadolu fay hattında bulunması nedeniyle Tokat kenti, 1498, 1826, 1887, 1916, 1940, 1943 tarihlerinde gerçekleşen depremlere tanklık etmiştir (Canik, 1986,s.245). 1498 yılında gerçekleşen ve kaynaklarda "Küçük Kıyamet" olarak da geçen depremde kent nüfusunun yarıya yakın bölümü dağılmıştır (Aktüre, 1978,s.145). 1590 ve 1597 yıllarında gerçekleşen iki büyük yangın ile pek çok anıtsal yapı hasar görmüş ve ahşap konut yok olmuştur. (Andreasyan, 1973,s.61). Ayrıca 1908 yılında gerçekleşen sel taşkını ile 1000 tane dükkanın yıkıldığı, binaların sürüklendiği ve insianların ölümüne sebep olduğu kaynaklarda yer almaktadır. (Cinlioğlu,1973, s. 52).

\subsubsection{Insana bağlı etkenler}

1601 yılında gerçekleşen Celali İsyanı ve 1627 yıllarında gerçekleşen benzer saldırılar ile kentin dış çeperindeki mahalleler yakılmıştır (Cinlioğlu, 1973, s. 52). 1914 yılında meydana gelen yangın kentte büyük kayıplara yol açmıştır. O tarihlerde Ermeni ve Rumlar'ın ticarethanelerinin ve evlerinin bulunduğu yer olan Cumhuriyet Meydanı'nda çıkan yangın, Sulusokak'a kadar iki yanda 80 evin, 91 dükkanın, 2 çeşmenin ve 3 hanın yok olmasına sebep olmuştur (Cinlioğlu,1973, s.60). 1886 yılında kentin ortasından yapılar yıkılarak bir kilometre uzunluğundaki Bağdat Caddesi günümüzdeki ismi ile Gaziosmanpaşa Caddesi açılmıştır (Cinlioğlu, 1973, s.38). 1960 yılında 
Karayolları idaresince, Samsun- Sivas yolunu açmak amacıyla kentin kuzey-güney yönünde bir tarihi hamamı pek çok tarihi konut yıkılmıştır (Kuntay, 1982,s. 11).

\subsubsection{Sosyal nedenler}

1455 tarihli Tokat Tahrir Defteri'ndeki kayıtlara göre 15.yy ortasında Tokat'ta yaklaşık 2000 Müslüman 1000 kadar da Hristiyan ailesi yaşamakta olduğu kayıt edilmiştir. Kentin mahalle sayısı 56 iken, bu mahallelerin 48' inde Müslüman, 6' sında Hristiyan ve 2' sinde ise Müslüman ve Hristiyanların bir arada olduğu görülmektedir. Kent nüfusunun üçte birini oluşturan gayrimüslimlerin kent merkezinde yer alan 8 mahallede ikamet etmesi, Müslüman halkın kentin çeperlerinde yoğunlaştığının göstergesidir (Aktüre, 1978, s.44). 1844-1845 Temettüat defter kayıtlarına göre ise, Tokat'ta 73 mahallenin 40 tanesinde Müslümanlar ile gayrimüslimlerin bir arada yaşadıkları yer alırken; toplam 73 mahalleden Müslümanların 52, Ermenilerin 51, Rumların 16, Katolik Ermenilerin 11, Yahudilerin 5 ve Kıptilerin (Çingene) 2 mahallede konumlandığı görülmüştür (Çavdar, 2014, s.457). Günümüzde geleneksel konut dokusunun yer aldığı, kentin eski ticaret merkezinin bulunduğu bölgede 20.yy başlarında gayrimüslimlerin zanaatkarların -bakırcılık, yazmacılık, kuyumculuk, dokumacılık işleri ile geçimini sağlayarak yakın çevredeki konutlarda ikamet ettiği kaynaklarda yer almaktadır (Arslanyan, 2012, s. 59-61). Nüfus dağılımındaki oranlardan anlaşıldığı üzere gayrimüslimlerin zamanla kentten ayrılması ile beraber (Açıkel, 2004,s.355) konut kullanıcıları ve dokuda yer alan etkin kullanıcı kimliğinin değişmesi sonucu sosyo-kültürel yapıdaki değişim; aidiyet duygusunun yok olmasına ve koruma anlayışının gelişmemesine bağlı olarak bozulmalara neden olmuştur.

\subsubsection{Yasal ve yönetsel nedenler}

Kültür ve Turizm Bakanlığı'nın 14.10.2010 tarih ve 79134 sayılı kararı ile uygun bulunan "Korunması Gerekli Doku ve Sokakları Sağlıklaştırma ve Kentsel Tasarım Projesi Teknik Şartnamesi" doğrultusunda hazırlanan, "Korunması Gerekli Sokakları Sağlıklaştırma Projesi"nin amacı; "Sınırları ilgili koruma bölge kurulunca onaylanan alanda tescilli ve tescilsiz taşınmaz kültür varlıklarının sokağa bakı veren cepheleri ile birlikte avlu duvarları, müştemilat, çeşme vb. mimari elemanların özgün sokak dokusu ve kentsel mobilyaları ile birlikte korunması, sağlıklaştırılarak yaşatılması ve çağdaş yaşama katılmasının sağlanmasının yanı sıra sokak dokusunu tanımlayan tüm öğelerin korunması ve belgelenmesine yönelik rölöve, restitüsyon, restorasyon, kentsel tasarım projeleri ile mühendislik dallarında yapılması gereken her türlü projenin elde edilmesidir" şeklinde ifade edilmiştir. Konutların yalnızca sokağa bakan ön cephesinde yapılan bakım ve onarımlar konutların yapısal ve strüktürel olarak onarılmamalarına ve dış görüntü olarak sağlam görüntü verip, var olan harabiyetin devam etmesine neden olmaktadır. Kültür varlığı yapıların korunmasına yönelik olarak yatırım programındaki mevcut bütçenin doğru bir strateji ile planlanarak kullanılmaması yasal anlamda geleneksel konutlara yönelik bir koruma sorunu oluşturmaktadır. 

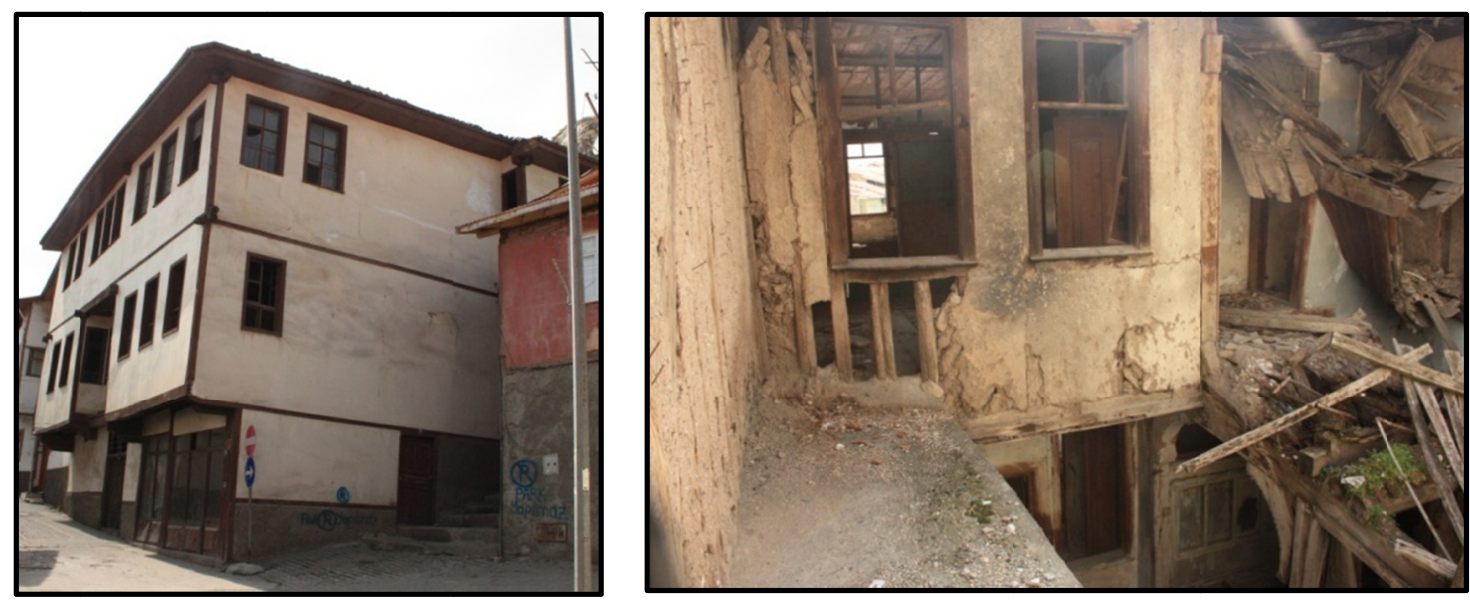

Şekil 24.-25. Bir konutun ön ve arka cephesi/ Halit Sokak (Yazar arşivi, 2013)

\subsection{Bozulma şekilleri}

\subsubsection{Biçimsel bozulmalar}

Konutlarda konum planı ölçeğinde gerçekleşen bozulmalar çoğunlukla konut kullanıcılarının gelişen yeni kullanım intiyaçlarını karşılamak amacıyla muhdes birimlerle yapıya ek yapılması ile ortaya çıkmaktadır. Plan düzenindeki bozulmalar; yeni mekân oluşturma, mekânı bölme ya da mekânları birleştirme şeklinde oluşabilmektedir. Günümüzde genellikle kullanımı tercih edilmeyen ahır, depo ve "iş evi" gibi konut birimleri konutlarda işlevsiz olduğu için boş bırakılarak ya da yeniden değerlendirilerek kullanılmaktadır. Konutların pek çoğunda zemin kata ıslak hacim eklenmiştir. Ara katı bulunan pek çok Geleneksel Tokat evinde yaz kış yiyeceklerin saklandığı birimin -soğukluk- işlevi değişerek farklı bir intiyaca yönelik kullanılmaktadır. Üst katlarda ise sofa, sedir, yüklük, gusülhanede intiyaç gereği değişiklikler yapıldığı görülmektedir. Geleneksel Tokat evlerinde cepheler plandaki değişmellere oranla daha az bozulmuş ve genellikle özgün biçimdedirler. Konutlardaki plan düzenlerindeki değişiklik cephelere kısmen daha az yansımıştır. Cephelerde gerçekleşen değişim iki şekilde oluşmuştur. Illki pencerelerin ve kapıların yenilenmesiyle oluşan değişikliğin cephe oranlarını bozması ile oluşan yüzeysel bozulma, ikincisi çıkma olarak görülen mekânların balkona dönüştürülmesi ile oluşan kütlesel bozulma olarak cephede kendini göstermektedir.

\subsubsection{Yapısal bozulmalar}

Ahşap konutlarda kaplamanın bozulmasına bağlı olarak suyun kiremit altı kaplamaları çatı kirişleri mertek ve aşıklarda oluşturduğu çürüme çarpılma eğilme kırıma gibi tahribatlar sonucu çatı konstrüksiyonu bozulmaktadır. Taşıyıcı sistem ile ilgili meydana gelen bozulmalar etkisiyle çıkmalarda da bozulmalar görülebilmektedir. Çıkma tabanındaki kirişleme sistemi ve bu sistemi taşıyan payandaların yapımı ya da detay hataları çıkmalarda sehim, düşeyden uzaklaşma ve sarkma gibi sonuçlar doğurmaktadır. Düzenli bakım olmamasından dolayı zaman içerisinde şi̧̧me ve kuruma ile birlikte çürüme, eskime, kırılma biçiminde bozulmalar yapının sabit yükleri olan kiriş ve taşıyıcı sisteminde görülebilmektedir. Tutuculuğu az olan sıva kullanımları, sıvanın bağdadi çıta veya sıva teli kullanılmadan doğrudan ahşap karkas arası kerpiç dolgu olan sisteme uygulanması ve sıvadaki yapım hataları ile düzenli olarak duvar kaplamalarının bakımının yapılmaması en önemli bozulma nedenlerini oluşturmaktadır. Konutlarda kullanılan çatı sisteminde düzenli olarak bakım yapılmaması, kuşların ve bir 
takım hayvanların kırarak kiremitlerde yarattığı tahribat sonucu üst örtü ile beraber çatı yapım sistemi hasar görerek yukarıdan içeriye girebilecek suya karşı y/apı savunmasız kalmaktadır. Yapı içerisinde ahşaba nüfus eden rutubet ahşabın içinde biyolojik canlıların oluşumuna zemin hazırlamaktadır. Yapıların döşeme tahtalarında meydana gelen bozulmaların nedeni ahşabın aşınması, yorulması ve mukavemetinin azalmasıdır. Konutlarda pencerelerle ilgili görülen en genel bozulma pencere boşluklarının kapatılması, büyütülmesi ya da küçültülmesidir. Pencerenin dış hava şartlarına maruz kalan ahşap kasa kanat ve pervazında çürüme şeklinde gelişen bozulma yaygındır. Tokat'ta genel olarak konutların iç ve dış kapıları özgünlüğünü korumaktadır. Konutlarda iç merdivenler taşıyıcı özeliğinin zamanla bozulması ve üstüne gelen yükler nedeniyle sehim yaparak deformasyona uğramıştır.

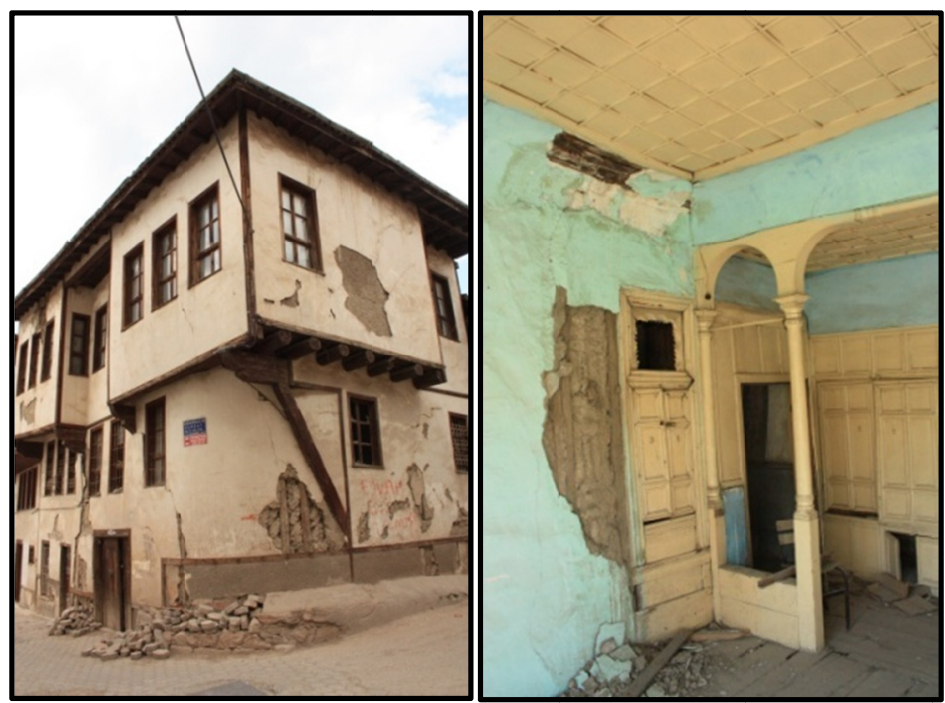

Şekil 26.-27. Cephe sıva ve iç duvar kaplaması bozulmaları / Bey Sokak (Yazar arşivi, 2013)
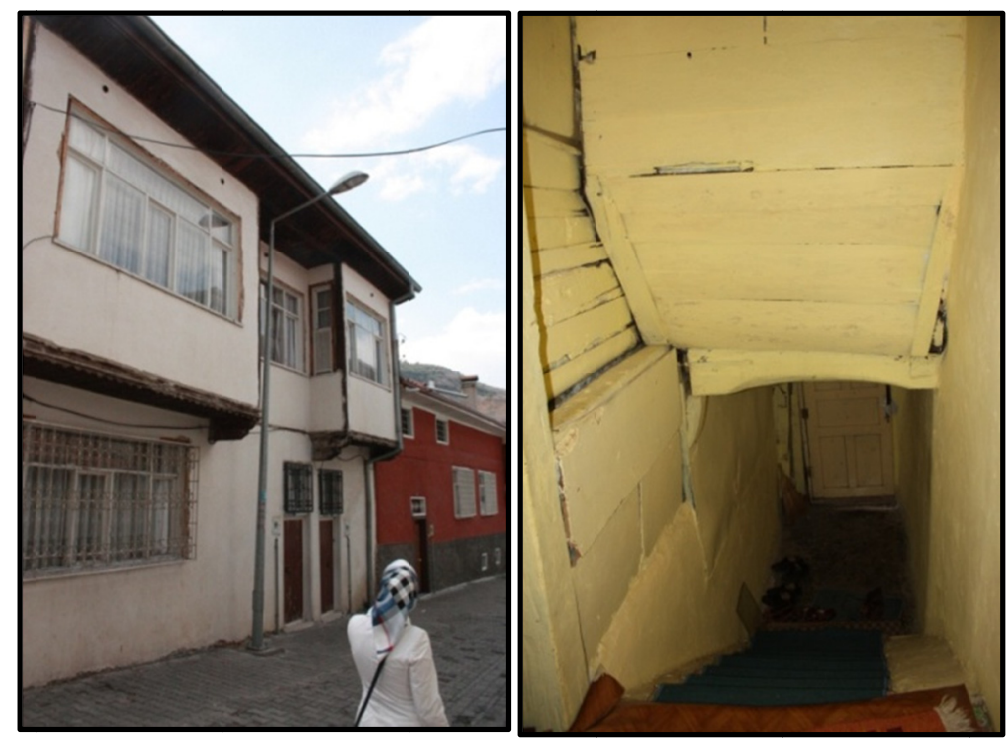

Şekil 28. Ön cephede özgün olmayan kapı-pencere oranları/ Beyhamam Sokak Şekil 29. Kapatılıp değiştirilen merdiven/ Halit Sokak (Yazar arşivi, 2013) 


\section{TOKAT KENTI GELENEKSEL KONUT DOKUSU IÇIN KORUMA YAKLAŞIMI ANALIZI}

Tokat kenti için zaman içerisinde geleneksel dokuda meydana gelerek kenti etkileyen ve dolaylı olarak konu özelinde irdelenen üç sokak içinde etkili olan bozulmaların nedenleri ile bu nedenlerin yarattığı bozulma şekilleri bir önceki başlık altında açıklanmıştır. Bu başlık altında Halit Sokak, Bey Sokak ve Beyhamam Sokak için alan ölçeği ve yapı ölçeğindeki sorunsallar analiz edilerek, Halit Sokak pilot çalışma alanı seçilmiş ve korumada öncelik sıralamasını belirleyen bir yöntemle çalışma gerçekleştirilmiştir. Pilot çalışma alanı olarak Halit Sokak'ın seçilmesindeki ölçüt ise sokak üzerindeki konutların yapısal ve biçimsel olarak çok çeşitli bozulma nedenlere sahip olduğunun gözlemlenmesidir.

\subsection{Alan ölçeğinde}

Yalnızca geleneksel konut dokusunun sürekliliğin bulunduğu sokaklar gerçekleştirilen "Sokak Sağlıklaştırma Çalışmaları" koruma bağlamında doku içinde alanı çekici kılıp, geleneksel dokuların değeri üzerine farkındalık yaratması açısından olumlu bir yaklaşım olarak görülebilir. Fakat taşınmaz kültür varlığı yapıların koruma yaklaşımının yalnızca yüzeysel cephe bakım ve onarım işlemi üzerinden ele alınması yetersiz ve riskli bir yaklaşımdır. Sokak sağlıklaştırma çalışmaları kapsamında korunan sokaklarda teknik şartname gereği rölöve, restitüsyon ve restorasyon projeleri hazırlanan her bir konutun uygulama aşamasında bütçenin yetersizliği ve doğru olmayan planlamalardan ötürü yalnızca konutun sokağa bakan ön cephelerinin onarılması çalışmasından öteye gidilemediği yapılan inceleme ve çözümlemeler sonucunda görülmüştür. Cephe onarımları dışında kapsamlı restorasyon projeleri ve uygulamalara kaynak olmadığında kaynakların öncelikli olarak özgün olarak günümüze ulaşmış ancak yapısal sağlamlık açısından risk altında olan nitelikli yapılar üzerinde kullanılması gerekmektedir. Tespit edilen nitelikli konutlar ile ilgili hazırlanacak koruma öncelik sırası çalışmaları doğrultusunda kaynağın doğru konutlara aktarımı sağlanabilir.

\subsection{Yapı ölçeğinde}

Yaşam koşullarının ve gerekliliklerinin değişimi ile çağdaş konfor anlayışıyla geleneksel düzen içinde kurgulanmış konutların örtüştürülememesi sonucu yapılan değişikliklerin özgünlüğün ve bütünlüğün sürekliliği için en önemli risk olduğu görülmüştür. Konutların özgün mekansal kurguları ya da mekan içindeki pek çok öğe kullanım dışı kalarak değişmektedir. Örneğin, depo, iş evi, ahır gibi konutların zemin kat ya da ara katında bulunan birimler ile üst katta yer alan sofada bulunan sedir, yüklükler, güsulhaneler değiştirilmiş ya da kaldırılmıştır. Tokat evlerinin iç sofalı plan tipinde olup zemin kat, ara kat ve 1. kattan oluşan mimari kurgusunda 1. katta yer alan güsulhanenin bu kata ayrı bir birim olarak eklenmesi mevcut plan kurgusunu bozacağı için bu gibi banyo, tuvalet, mutfak gibi hacimleri zemin kata çözümlenmelidir. Geleneksel Tokat Evleri'nde plan ölçeğinde bozulmanın en önemli nedenlerinden biri de tek bir konutun birden fazla aile tarafından kullanımıdır. Tek bir kullanıcı için kurgulanan plan şeması bu şekilde bir bölünme ile farklı intiyaçları beraberinde getirmektedir.

\subsection{Pilot çalışma}


Yapı ölçeğinde ve alan ölçeğindeki koruma sorunlarının tespiti ile korumada öncelik sıralamasını belirlemek için bir yönteme intiyaç duyulması sebebiyle pilot çalışma alanı olarak seçilen Halit Sokak üzerindeki konutlara Binan'ın korunması gerekli konutlar için geliştirdiği (Binan, 1994,s. 237, 2013,s. 1-26) "dış gözlem ile çözümleme ve korumada öncelikleri belirleme" yöntemi uygulanmıştır. Bu yöntem ile çalışma kapsamında, Halit Sokak üzerinde mevcut 5 adet tescilli konut örneği dışında, yapılan alan çalışması sonucu tescillenmesi önerilen konutların da çalışmaya dahil edilmesiyle 7 adet konut örneğinin sorgulaması yapılmıştır. Pilot çalışma için seçilen konutlar tescilli ve tescile önerilen özgün ve nitelikli sivil mimarlık örnekleri olup, korunmaları için kapsamlı onarım-restorasyon gerekirken sokak sağlıklaştırma çalışmasıyla sadece yüzeysel bir cephe koruma uygulamasının yapıldığı yapılardır. Bu koruma yaklaşımına yönelik sorgulama ve öneri geliştirme gereğidir. 7 adet korunması gerekli konut üzerinden yapılan pilot çalışmanın; kapsamının genişletilerek sokak bütününde yer alan tüm konutlar için bozulma durumları değerlendirilerek, korumada öncelikli yapıların tespit edilmesi mümkündür. Konutların "bozulma durumuna" göre puanlama yapılmıştır. Bozulmalarda incelenen her bir öğenin kendi bütünlüğü içindeki bozulma yüzdesi dikkate alınarak tablolar oluşturulmuştur. İncelenen öğe ile ilgili \%25 (1/4) lik bozulma "az bozulmuş", \%50 (2/4) lik bozulma "orta bozulmuş", \%75 (3/4) lik bozulma "çok bozulmuş", \%100 (4/4) lük bozulma "harap" olarak belirlenen ölçüt puanı, taşıyıcı sistemden yapı elemanına uzanan yapısal bozulma etkisinin önemine bağlı olarak bir katsayı (Binan, 1994, s.239) ile çarpılarak tablo oluşturulmuştur. Tablolarda belirlenen Yapısal Bozulmuşluk Durumu katsayılarının tanımlamalarının kapsamı şu şekildedir (Binan, 2013, s. 20):

- Az Bozulmuş (Íyi): Taşıyıcı sisteme ulaşmayan küçük malzeme bozulmaları

- Orta Bozulmuş (Orta): Yapı elemanlarının ( pencere, kapı, çıkma, kat silmesi, saçak silmesi, çörten, baca, vs) bozulması ve özgün yapı elemanlarının kısmen yok olması, değiştirilmesi koruyucu sistem (örtü kaplaması, duvar örgüsü) deki bozulmalar.

- Çok Bozulmuş (Kötü):Taşıyıcı sistemin(düşey taşıyıcı, yatay taşıyıcı, eğrisel örtüler) taşıyıcılık özelliklerinin azalması ya da yok olması, genel plan düzeninin ve plan elemanlarının (oda, sofa, merdiven, vs.) bozulması, cephe düzeninin (kat adeti, dolu boş oranı, kütle etkisi, yüzey etkisi, çatı düzeninin) bozulmaları.

- Harap: Tanımlanması zor olan ya da tanımlanamaz nitelikte kalıntılar.

Biçimsel ve yapısal bozulma durumunu gösteren her bir puanlama tabloların alt başlıklarındaki maddelerle beraber toplam öncelik sırasını belirlemiştir. Belirlenen bu öncelik sırası konutların biçimsel ve yapısal bozulmasındaki müdahale sırasını göstermektedir. İncelenen biçimsel ve yapısal bozulma durumu çözümleme tablosundaki puanlamalara ek olarak konutların izlenim, sanat, belgesel ve ekonomik değerlerinin puanlaması yapılmıştır. Bu değerler tablo da görüldüğü gibi alt başlıklarda izlenim, sanat, tarihi, özgünlük, eskilik, enderlik ve yöresellik değerleri olarak ele alınmıştır. Özgünlük ölçütü için yapılan puanlama ile ilgili tanımlamaların kapsamı şu şekildedir (Binan, 2013, s.20-21):

- Iyi: Yapının üst örtü kaplaması, duvar kaplaması ile yapı elemanların da, bezeme de ve malzeme de kısmı yok oluş.

- Orta: Konum planı ölçeğinde (yapı parsel ilişkisi, yapı sokak ilişkisinde) değişme, genel plan düzeninde ve/veya cephe düzeninde (yüzey etkisi, çatı düzeninde) kısmi yokoluş ve değişme. 
- Kötü : Genel plan düzeninde, cephe düzeninde (kat adeti, dolu boş oranı, kütle etkisi, yüzey etkisi, çatı düzeninde) ve yapı elemanların da, malzeme de yok oluş ve değişme.

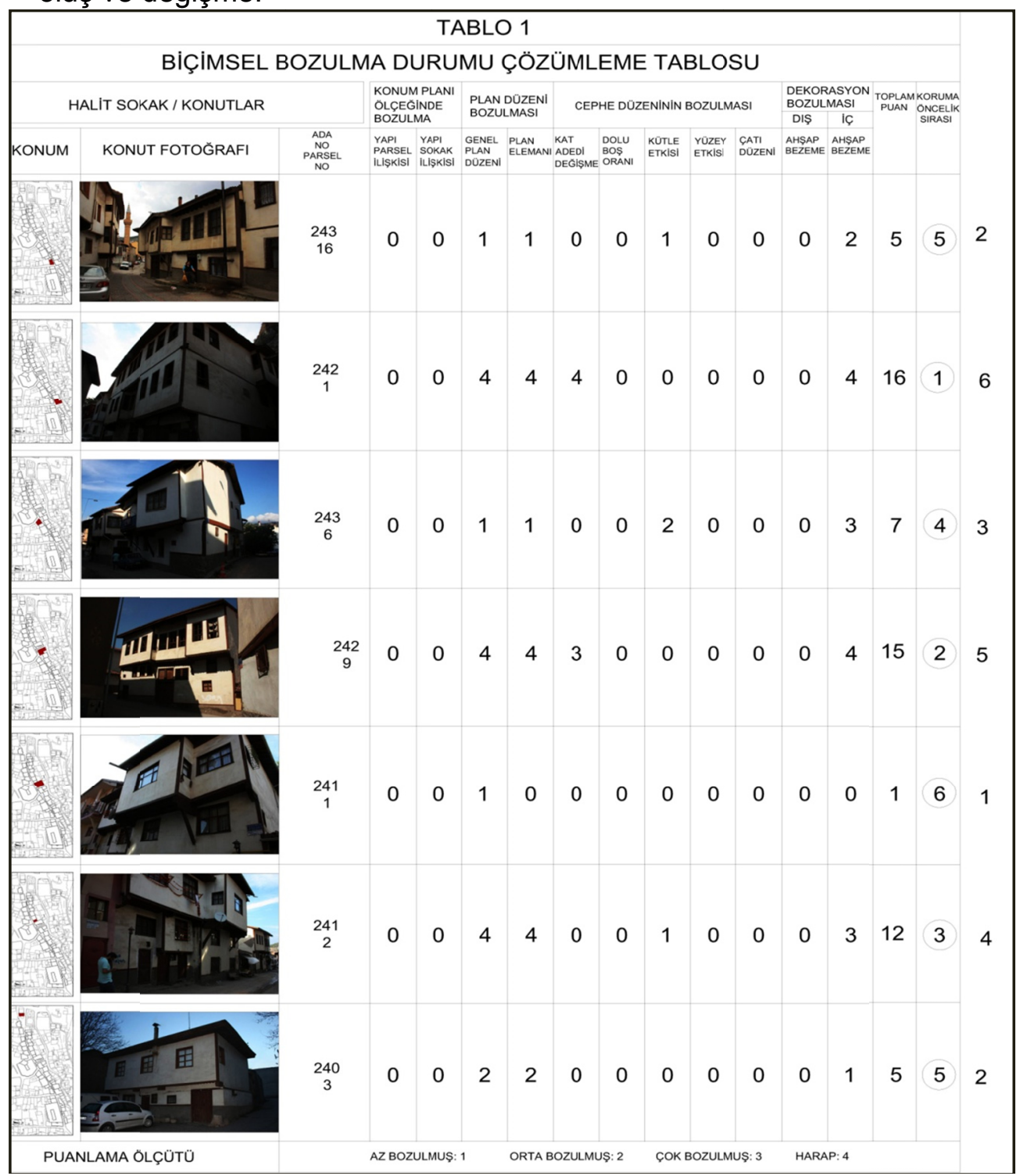

Şekil 30. Biçimsel bozulma durumu çözümleme tablosu

Biçimsel bozulma durumu çözümleme tablosuna göre, örneğin, 243 ada 16 pars numaralı konutun plan düzeni bozulma başlığı altındaki genel plan düzeni bozulma alan çalışmasında az bozulmuş olarak değerlendirildiği için tabloda 1 puan (bozuln yoksa 0 , az bozulmuş:1, orta bozulmuş:2, çok bozulmuş:3, harap:4 puan) yazılar: belirtilmiştir. Bu puanlamalar konutun tüm bozulma özellikleri için yapılarak sonuç pué toplanmıştır. Tablo değerleri sonucu puanlama konutun biçimsel bıozulma durun.. puanı olup, toplamı yüksek olan konut korumada öncelikli müdahalenin gerektiği konut olarak belirlenir. En sağdaki sütunda ise bozulma durumlarına göre sıralama yapılmıştır. 


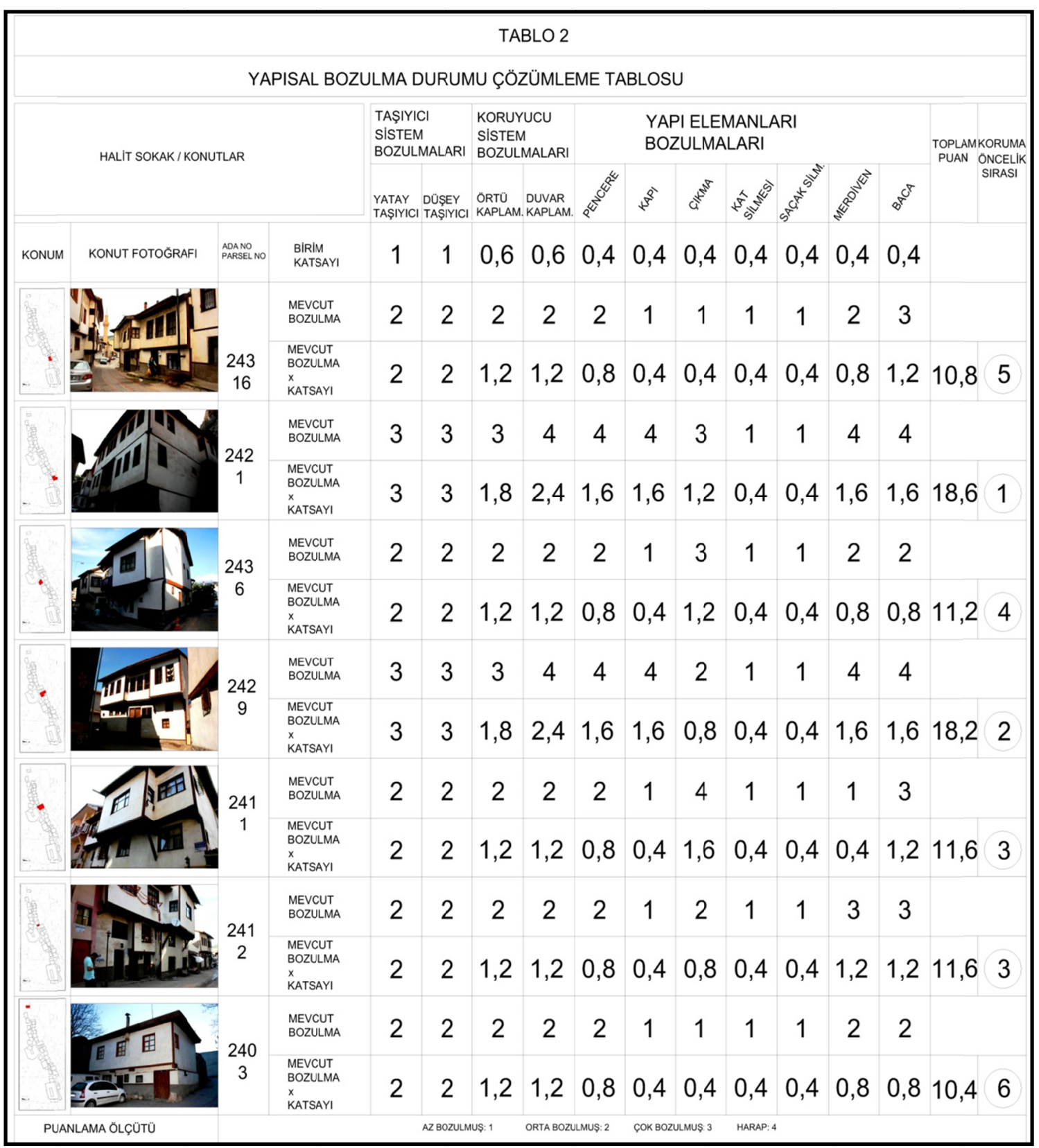

Şekil 31. Yapısal bozulma durumu çözümleme tablosu

Yapısal bozulma durumu çözümleme tablosuna göre, örneğin, 243 ada 16 parsel numaralı konutun taşıyıcı sistem bozulmaları başığı altındaki yatay taşıyıcı bozulması alan çalışmasında orta bozulmuş olarak değerlendirildiği içim tabloda 2 puan (bozulma yoksa 0, az bozulmuş :1, orta bozulmuş:2, çok bozulmuş:3, harap:4 puan) yazılarak mevcut bozulma puanı belirtilmiştir. Bu puanlama bozulmanın önemine göre katsayısı 1 ile çarpılmış ve bunun sonucu da mevcut bozulma $x$ katsayı olarak belirtilmiştir. Tablo değerleri sonucu puanlama konutun yapısal bozulma durumu puanı olup, toplamı yüksek olan konut korumada öncelikli müdahalenin gerektiği konut olarak belirlenir. 


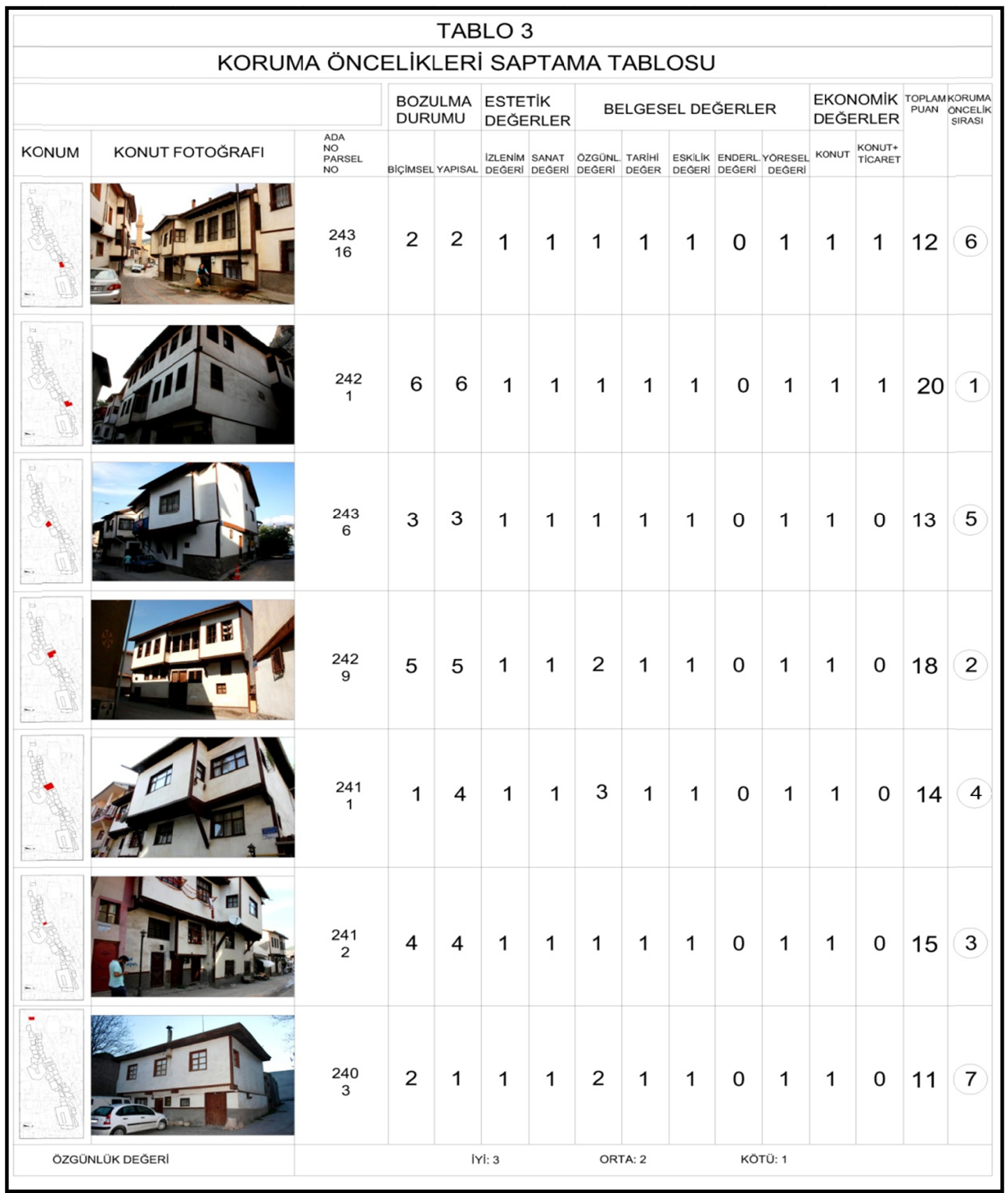

Şekil 32. Koruma öncelikleri saptama tablosu

Koruma öncelikleri saptama tablosuna göre, örneğin 243 ada, 16 parsel numaralı konutun biçimsel bozulma tablosunda toplam 5 puan ile bozulma durumu 2. sırada yer alan konut olup, yapısal bozulma tablosunda toplam 10.8 puan ile de 2. sırada yer alan konut olarak görülmektedir. Tabloya bu ilk iki sütunun önceki tablolarda belirlenmiş mevcut bozulma durumu verileri eklendikten sonra, diğer bölümlerde yer alan değerler(estetik, belgesel, ekonomik) puanlaması, 1:kötü, 2:orta, 3: iyi şeklinde tabloya yerleştirilerek toplam puanı en yüksek olan, korumada en öncelikli olarak müdahale edilmesi gereken konut olarak belirlenmiştir.

\section{SONUÇ ve DEĞERLENDİRME}

Tokat kenti kale merkezinde şekillenen tarihi dokusu farklı kültür ve medeniyete tanıklık etmiştir. İlk yerleşim merkezi gelişerek farklı dönemlerde inşa edilen hanlar, camiler, hamamlar, medreseler ve geleneksel konutlar ile tarihsel bir doku oluşturmuştur. 
Geleneksel konut dokusu ticaret akslarının çeperlerinde yer almaktadır. Ticarette aktif olarak yer edinen, gayrimüslimlerin 18.yy'da kente göçü ile kültürel ve sosyal olarak kent değişim içine girmiştir. Tarım ile uğraşan yerli halkın aksine kentte dokumacılık, bakırcılık, dericilik, yazmacılık gibi pek çok zanaatı gerçekleştiren gayrimüslimlerin 20. yy'ın başından ortasına kadarki süreçte kentten ayrılması, mevcut ticaret hareketliliğini zayıflatmıştır. Mevcut ticaret hareketinin zayıflaması ile günümüze kadar ulaşan geleneksel konut dokusunun olduğu alan bir çekim merkezi olmaktan çıkarmıştır. Günümüzde geleneksel konut dokusunun bulunduğu alanlardaki kullanıcı değişikliğinin beraberinde getirdiği sosyal yapıdaki değişim, güncel konutların çağdaş kullanıma imkan sağlayacak mekânları ve donatıları barındırmaması, konutların birden fazla kiracıya verilip bölünerek mekânsal organizasyonun değiştirilmesi ve geleneksel konutlarda yaşayan kullanıcılarda koruma bilincinin yeterince gelişmemiş olması konutların tahrip olmasına neden olmaktadır. Dokuyu oluşturan geleneksel konutların korunamamasına zemin hazırlayan bu durum sivil mimari örneklerin pek çoğunun günümüze ulaşmasını da engelleyici bir unsur olarak görülebilir.

Koruma uygulamalarında yüzeysel bir cephe sıhhileştirmesi olarak ele alınan sokak sağlıklaştırma çalışmaları, kentte yer alan geleneksel konut dokusunun yoğunlaştığı sokaklarda uygulanarak var olan değerlerine farkındalık sağlamak amacına hizmet eden olumlu bir yaklaşım olarak görülmekle birlikte yapılardaki yapısal bozulmaları kamufle eden, bütüncül onarımı sağlayamayan bir sonuca neden olmaktadır. Sokak özelinde, alanın çekim merkezine dönüşmesi için gerçekleştirilen bu yaklaşım, kentin kültürel ve tarihi merkezinde yer alan çok sayıdaki korunması gerekli geleneksel konutların korunmasına yönelik gerekli kaynak, bütçe ve zamanın aktarılmasını geciktirebilir.

Pilot çalışma, sokak sağlıklaştırma çalışması yapılmış olan Halit Sokak'ta yedi adet korunması gerekli kültür varlığı niteliğine sahip konutların örnekliği üzerinden geleneksel konutların bulunduğu sokak ve dokulara uygulanabilecek bir model önerisi niteliğinde yapılmıştır. İlk aşamada bozulma durumları üzerinden yüzdelik oranlar ile korumada öncelik sıralamasını gösteren puanlama tablosu oluşturulmuştur. Biçimsel ve yapısal bozulma durumu üzerinden farklı iki ayrı tabloda bozulma durumları belirlenerek fiziksel bozulma durumu için öncelikli müdahale gerektiren konutlar tespit edilmiştir. Yapılan değerlendirmede sokak sağıklaştırma çalışması yapılarak cephe görünümü iyileştirilen konutların yapısal olarak taşıyıcı sistemlerinin kötü ya da harap durumda olduğu ve kapsamlı onarım-restorasyon gerektirdiği tespit edilmiştir. Değerlendirilmeye alınan konutlardan koruma sıralamasının belirlenmesi ile koruma uygulamalarına ayrılan bütçenin öncelikli konutlar üzerinden kullanımının sağlanması mümkün olacaktır.

\section{7. ÖNERILER}

Tokat kentinde mevcutta koruma altına alınarak tescillenen pek çok konut olduğu gibi envanteri ve tescili olmayan kültür varlığı sivil mimari örneklerinin varlığı alan çalışmalarında görülmüştür. Bu ve benzeri konutların gecikmeden belgelenmesi ve korunmasına yönelik tedbirlerin alınması koruma için önemlidir. Tarihi doku çeperindeki tescilli ya da tescilsiz tüm geleneksel konutların mevcut durumları detaylı ve sistemli bir belgeleme-envanterleme çalışmasından sonra korumada öncelikli müdahale edilecek konutların belirlemesi yapılmalıdır. Geleneksel konutların belirli aralıklar ile düzenli olarak bakım ve onarımlarının yapılması için, konutta ikamet eden kiracı ya da ev sahiplerinin konu ile ilgili detaylı bir şekilde bilgilendirilmesi ve bilinçlenmesi ile kullanıcı olarak onların da aktif olarak koruma sürecine dahil olabileceği bir yaklaşım geliştirilmesi geleneksel konut dokusunun korunmasındaki en önemli adımlarındandır. 
Sokak özelinde gerçekleştirilen sokak sağlıklaştırma çalışmalarının yüzeysel bir ön görünüş bakım onarım uygulaması olarak değil de, kapsamı ve içeriği geliştirilip zenginleştirilerek ele alınması önerilmektedir. Yeni bir sokak sağlıklaştırma tanım ve çerçevesi geliştirilerek müdahale için biçimsel ve yapısal bozulma durumu bağlamında korumada öncelikler oluşturulmalıdır. Bu bağlamda, makale içeriğinde pilot çalışma alanında yer alan konutlar üzerinden tablolaştırılarak yapılan değerlendirme ve puanlama yöntemi, Tokat kentinden geleneksel kont dokularına uyarlanarak örnek alınabilecek bir model önerisi olarak sunulmaktadır.

Geleneksel mimari mirasın tanımlanması, değerlendirilmesi ve korunması açısından; 2863 sayılı yasa ve 660 sayılı ilke kararları kültürel mirasın korunması ve değerlendirilmesine yönelik ilkeler, ölçütler ve politikalar geliştirmek, ilgili araştırmaları desteklemek ve yönlendirmek yolunda uluslararası sivil toplum kuruluşu ICOMOS'un ${ }^{5}$ kültürel mirasın korunmasıyla ilgili tüzüklerindeki koruma yaklaşım ve ölçütlerinden faydalanmak gerekmektedir. Bu tüzüklerden tarihi dokunun korunması ve alan ölçeğinde koruma ve gelişme için ;

- 1987 yılında Washington'da yapılan, ICOMOS Genel Kurulu'nda kabul edilen, küçük veya büyük tarihi kentsel alanlarla ilgili; kentleri ve tarihi merkezleri saran doğal ve insan yapısı çevreyi de kapsayan: "Tarihi Kentlerin ve Kentsel Alanların Korunması Tüzüğ̈̈",

- 2011 yılında Paris'te yapılan ICOMOS Genel Kurulu'nda kabul edilen, tarihi kentlerde ve kentsel alanlarda yapılacak her tür müdahaleye uygulanabilir ilke ve stratejiler önermeyi amaçlayan: "Tarihi Kent ve Kentsel Alanların Korunması ve Yönetimi için Valetta IIlkeleri" ${ }^{7}$ verilebilir.

Tarihi doku ile ilgili alan ölçeğindeki kararlar ile beraber tek yapı ölçeğinde koruma yaklaşım ve müdahale planı oluşturmak için de faydalanılabilecek olan tüzükler olarak da;

- 2012-2013 tarihleri arasında gerçekleştirilen, Ulusal Mimari Koruma Uzmanları Toplantıları ve ICOMOS Türkiye Milli Komitesi'nin revizyonu ile son şekli verilen, koruma sürecinde yer alan tüm disiplinler ve toplumun farklı kesimleri için mimari mirası korumanın temel ilkelerini tanımlayan, mimari mirasa yönelik tanımları, korumanın süreç ve araçlarını, koruma eğitimi ve politikalarını, korumanın topluma mal edilmesi konularını içeren ve Türkiye ölçeğinde kamuoyuyla paylaşılacak ve içselleştirilecek bir kültür politikasına kaynak oluşturması amacıyla hazırlanan: "ICOMOS Türkiye Mimari Mirası Koruma Bildirgesi" ${ }^{8}$

- 2017 yılında Yeni Delhi'de yapılan, 19. ICOMOS Genel Kurulu'nda kabul edilen, 1999 yılında kabul edilmiş olan "Tarihi Ahşap Yapıların Korunması için İlkeler" in güncellenmesi amacı ile yazılan: "Ahşap Mimari Mirasın Korunması İçin IIlkeler (Principles For The Conservation of Wooden Built Heritage)" 9 verilebilir. Belirtilen yasal ve çağdaş koruma yaklaşımı doğrultusunda, Tokat kenti için korumada devamlılığı sağlanabilecek bir koruma stratejisi ve planlama yaklaşımı geliştirilerek, Valilik, Kültür ve Turizm Bakanlığı ve TOKI'nin taşınmaz kültür varlıklarının

\footnotetext{
${ }^{5}$ Uluslararası Anıtlar ve Sitler Konseyi/ International Council on Monuments and Sites: www.icomos.org.tr

${ }^{6} \mathrm{http}: / /$ www.icomos.org.tr/Dosyalar/ICOMOSTR_0884650001353670152.pdf

${ }^{7} \mathrm{http}: / /$ www.icomos.org.tr/Dosyalar/ICOMOSTR_0812398001518162308.pdf

${ }^{8} \mathrm{http}: / /$ www.icomos.org.tr/Dosyalar/ICOMOSTR_0623153001387886624.pdf

${ }^{9} \mathrm{http}: / / w w w . i c o m o s . o r g . t r / D o s y a l a r / I C O M O S T R \_0153541001523006751 . p d f$
} 
korunmasına yönelik proje ve uygulamaları kapsayan fonlarından yararlanmak için belediyenin ve KUDEB'in görev üstlenmesi ve bu fonların geleneksel konutların korunmasına yönlendirilmesinin sağlanması gerekmektedir. Onarımlar için geleneksel yapım malzemesi ve yapı ustası temini ve gelişiminin sağlanmasına yönelik adımlar atılmalıdır. Korumaya ayrılacak bütçenin doğru paylaşımı için ayrıntılı bir şekilde gerçekleştirilen belgeleme ve envanterleme süreçleri sonrası konutların korumada öncelikli olanların belirlenmesi ve bu doğrultuda koruma yaklaşımının geliştirilmesi gereklidir.

\section{KAYNAKLAR}

Açıkel, Ali, "Tokat Sancağının Idari Durumu ve Nüfus Yapısı (1880-1907)", Fırat Üniversitesi Sosyal Bilimler Dergisi, Elazığ 2004, 14(2): 331-359

Andreasyan, Hırand, “Eremya Çelebi'nin Yangınlar Tarihi”, İstanbul Üniversitesi Edebiyat Fakültesi Tarih Dergisi, İstanbul 1974, 27: ss.59-84/61

Anonim, “Tokat”, Yurt Ansiklopedisi, Cilt X, Anadolu Yayıncılık, İstanbul 1984, ss.7085

Aksulu, Işık, "Kaybolan Bir Mirasın Ardından Tokat Kenti Ve Koruma Sorunları", Osmanlı Mimarlığının 7. yy Uluslarüstü Bir Miras", Yapı Endüstri Merkezi Yayınları, Tunç Matbaacılık, İstanbul 1999, ss. 343

Aktüre, Sevgi, "19. Yüzyıl Sonunda Anadolu Kenti Mekânsal Yapı Çözümlemesi”, ODTÜ Mimarlık Fakültesi Baskı Atölyesi, Ankara 1978, ss.44/144-145/159

Akyüz, Abdurrahman; Yetişkin, Güven; İçen, Saliha; Teksarı, Yahya, "Tokat Merkez Ve Il/çeleri Taşınmaz Kültür Ve Tabiat Varlıkları Envanteri”, Tokat Valiliği Yayını, Tokat 2010, ss:1-492

Arslanyan, Agop, “Adım Agop Memleketim Tokat”, Aras Yayıncılık, İstanbul 2012, ss.88/59-61

Binan Ulusoy, Demet, "Güzelyurt Örneğinde Kapadokya Bölgesi Yığma Taş Konut Mimarisinin Korunması İçin Bir Yöntem Araştırması", Yıldız Teknik Üniversitesi Fen Bilimleri Enstitüsü Yayını, Id No :75256, İstanbul 1994, ss.237-239

Binan Ulusoy, Demet, "Türkiye'de Çok Katmanlı Yerleşimlerde Tanımlama-Koruma Yaklaşımı Ve Öneriler: Bergama Örneği”, Tasarım+Kuram Dergisi, Mimar Sinan Güzel Sanatlar Üniversitesi Mimarlık Fak. Yay., Issn: 13022636, İstanbul 2013, ss.9(16): 1-26

Canik, Baki, "Tokat'ın Depremselliği Ve Tarihte Geçirdiği Depremler", Türk Tarihinde Ve Kültüründe Tokat Sempozyumu, Türkiye: Gelişim Matbaası, Ankara 1986, ss.245

Cinlioğlu, Halis Turgut, "Osmanlılar Zamanında Tokat", 4. Cilt, Barış Matbaası, Tokat 1973 , ss. 38/52/60

Çal, Halit., “Tokat Evleri”, I. Baskı, Kültür Ve Turizm Bakanlığı Yayınları, Ankara 1988, ss. $30 / 32$

Çavdar, Necati, "XIX Yüzyıl Ortalarında Tokat'ta Katolik Ermeniler: DemografiEkonomi", Yeni Türkiye, İstanbul 2014, ss.1(60): 457 
Kuntay, Orhan, "Tokat Kentinin Tarihsel Gelişmesi Ve Imar Planı Çalışmalarına Yardımcı Bir Araştırma”, Ktü-İnşaat Mimarlık Fakültesi Kent Ve Bölge Araştırmaları Enstitüsü Yayını, Trabzon 1982, ss.10-11

Ünver, Hasan, "Sokak Sağlıklaştırmanın Tanımsal Olarak Irdelenmesi", Düzce Üniversitesi Bilim Ve Teknoloji Dergisi, Sayı 5, Düzce 2017, ss.97-98

Yavi, Ersal, “Tokat”, Güzel Sanatlar Matbaası A.Ş., İstanbul 1986, ss.99/101

Kültür Varlıkları ve Müzeler Genel Müdürlüğü Arşivi

Sivas Kültür Varlıklarını Koruma Bölge Kurulu Müdürlüğü Arşivi

Tokat Koruma Uygulama ve Denetim Bürosu(KUDEB) Arşivi

Tokat Belediyesi ve Tokat Valiliği Çevre ve Şehircilik İı Müdürlüğü Arşivi

http://www.kulturvarliklari.gov.tr/TR,51992/kultur-varliklari-ihale-yonetmeligi-25072013tarih-ve-2-.html (E.T. 13.08.2018)

http://www.icomos.org.tr/?Sayfa=Tuzukler1\&dil=tr (E.T. 13.08.2018) 